\title{
The impact of geological uncertainty on primary production from a fluvial reservoir
}

\author{
Mohammad Koneshloo ${ }^{1} \cdot$ Saman A. Aryana ${ }^{1,2} \cdot$ Xiaoni Hu$^{3}$
}

Received: 4 July 2017 / Published online: 21 April 2018

(C) The Author(s) 2018

\begin{abstract}
Deposition of fluvial sandbodies is controlled mainly by characteristics of the system, such as the rate of avulsion and aggradation of the fluvial channels and their geometry. The impact and the interaction of these parameters have not received adequate attention. In this paper, the impact of geological uncertainty resulting from the interpretation of the fluvial geometry, maximum depth of channels, and their avulsion rates on primary production is studied for fluvial reservoirs. Several meandering reservoirs were generated using a process-mimicking package by varying several controlling factors. Simulation results indicate that geometrical parameters of the fluvial channels impact cumulative production during primary production more significantly than their avulsion rate. The most significant factor appears to be the maximum depth of fluvial channels. The overall net-to-gross ratio is closely correlated with the cumulative oil production of the field, but cumulative production values for individual wells do not appear to be correlated with the local net-to-gross ratio calculated in the vicinity of each well. Connectedness of the sandbodies to each well, defined based on the minimum time-of-flight from each block to the well, appears to be a more reliable indicator of well-scale production.
\end{abstract}

Keywords Geological uncertainty evaluation - Fluvial reservoir modeling · Process-mimicking simulation ·

Geometry of fluvial channels

\section{Introduction}

Fluvial reservoirs are heterogeneous at a multitude of scales. High-permeability contrasts between mud and sand deposits make the connectivity of sandbodies the main controlling factor for reservoir quality. The internal structures of sediments on a small scale (core and pore scales) and stratigraphic correlation of fluvial formations on a large scale have received more attention than the architecture of depositions, the geometry of channels, and conserved sandbodies, which are more important for the

Edited by Jie Hao

Mohammad Koneshloo

mkoneshl@uwyo.edu

1 Department of Petroleum Engineering, University of Wyoming, Laramie, WY 87061, USA

2 Department of Chemical Engineering, University of Wyoming, Laramie, WY 87061, USA

3 Department of Geological Sciences, University of Wyoming, Laramie, WY 87061, USA geological modeling of a reservoir (Gibling 2006). The sources of geological uncertainty are classified by Massonnat (2000) in a six-level hierarchical chart: data acquisition, interpretation of data, geological concept elaboration, the spatial distribution of geological features, choice of the input parameters, and generation of equiprobable realizations. Despite the importance of these factors, geological models are assumed fixed or predetermined in many routine industrial appraisal projects, and practitioners often prefer to focus only on one fine geological model and to analyze only the impact of dynamic parameters. Laure and Hovadik (2008) state two reasons for this lack of attention; first, it is believed that reservoir architecture is a less important factor in oil production than other petrophysical and fluid properties or the operational parameters of a reservoir. Second, generating realistic subsurface models is a difficult and time-consuming task. In fact, the first reason may be true only if the lithological facies demonstrate similar patterns or exhibit similar connectivity despite their different patterns. The difficulty of subsurface modeling resides in its uncertain nature coming from lack of subsurface data which lead to various possible 
interpretations of the geological settings, where the sedimentological and structural factors are thought to be the major sources of uncertainty. A specific geological model, however, can never capture the full range of geological uncertainty of a reservoir (Caumon and Journel 2005). Fluvial reservoirs and especially meandering deposits appear to demonstrate the importance of reservoir architecture in project appraisal. The architecture of the meandering deposits, formed by multi-story channel deposits separated by floodplain mud, is complex as a result of lateral migration and avulsion. The sand fraction is known as the dominant factor in evaluation of a fluvial reservoir, while the geometry of channels, avulsion rate, and direction of point-bar migration are also significant (Jones et al. 2009). These factors also determine the connectivity of sandbodies (high permeable regions), which is a dominant factor influencing fluid flow and shaping preferential flow pathways in reservoirs (Pranter and Sommer 2011). All of these characteristics are controlled by the geological parameters of the system. Correct estimation of sandbodies and their topological relationships are key elements in understanding these reservoirs. This paper aims to demonstrate the impact of the geometry of fluvial channels and avulsion rates on the quality of a fluvial reservoir.

Numerical reservoir modeling is a commonly used tool for analyzing the impact of geological features on production. Most stochastic reservoir modeling methods rely on spatial correlation and well data to generate representative models. In such a framework, it is difficult to incorporate physical laws of sedimentation and prevent geologically incorrect placement of sandbodies (Tye 2013). Methods such as object-based methods (Pyrcz and Deutsch 2014) and multiple-point geostatistics (Strebelle 2002; Rezaee et al. 2013) rely on predefined patterns or objects, which are the consequence of sedimentation under a defined set of geological factors. Process-based simulators are tools developed to mimic the sedimentation process and to evaluate the impact of geological factors directly (Deviese 2010; Hajek and Wolinsky 2012). Most processbased simulators incorporate a simplified equation of flow to mimic processes governing deposition of sediments (Cojan et al. 2005). In this study, subsurface models are generated using FLUMY, a process-mimicking software for meandering systems (Koneshloo et al. 2017).

This work focuses on levels three and four of the Massonnat (2000) hierarchical classification of the sources of uncertainty: elaboration of the geological model and explanation of the main factors controlling the distribution of the geological features in a meandering reservoir. According to Tye (2013), the most important factors controlling the static connectivity of sedimentary sandbodies are channel widths and net-to-gross ratio (NGR) values. Although NGR values calculated using well data (1-D) are generally used as acceptable approximations of the reservoir NGR, the interpretation of the shape and lateral extension of sedimentary features solely based on vertical data is rather difficult. In this work, several models are generated to study the impact of uncertainty inherent in subsurface model conceptualization and the controlling factors. The following sections describe the geometry of channels, present several empirical equations used to explain the geometry of channels, and discuss ambiguities in their application. Petrophysical models are generated, and oil production from each model is simulated. Fieldlevel and well-level results are compared, and the impact of various geological factors on cumulative primary production is analyzed.

\section{Materials and methods}

In geometrical modeling of a reservoir's features, we are often faced with a scarcity of data. Three-dimensional seismic data are often used to generate pseudo-images of the subsurface. Several studies show that incised valleys, channel belts, large channels (with a thickness above the seismic vertical resolution), and abandoned channels filled with coaly horizons are seismically detectable (Alsouki et al. 2014; Zhang et al. 2015). In the absence of seismic data, outcrops and modern deposition systems are important sources of information related to sedimentary features. For a given reservoir, architecture dictates the spatial distribution of reservoir properties within the reservoir. The distinction between all sedimentological features and reliable estimation of their geometrical parameters are not always possible. Although core and log data have good vertical resolutions, lateral continuity cannot be extracted directly from such data.

Miall (2014) illustrates the uncertainty inherent in geological modeling using three interpreted sections of zone one of the Travis Peak Formation. In this study, three different empirical equations are used to estimate channel widths based on their depths (Bridge and Mackey 2009; Leeder 1973; Williams 1986). Due to differences in assumptions, the same logs result in three completely different representations of the subsurface in terms of the connectivity of sandbodies. Additional challenges include synonymous use of terms (e.g., meander belt and channel) and inconsistent estimation of influential parameters (e.g., width of fluvial channels may be estimated based on either maximum bankfull depth, or mean bankfull depth of the channels, or thickness of sandbodies). Finally, these variables must often be inferred based on limited one-dimensional data. Table 1 shows the most commonly used empirical equations for the estimation of lateral extension 
Table 1 Summary of empirical equations for the estimation of the geometry of fluvial systems

\begin{tabular}{|c|c|c|c|}
\hline Model & Parameters & How to measure & Limitations \\
\hline $\begin{array}{l}\text { Bridge and Tye }(2000) \\
W_{c}=8.8 \times H_{\text {mean }}^{1.88}\end{array}$ & $\begin{array}{l}H_{\max }: \text { Bankfull } \\
\text { channel depth, } \\
\text { m } \\
H_{\text {mean }}: \text { Mean } \\
\text { bankfull } \\
\text { channel depth, } \\
\text { m } \\
W_{c}: \text { Channel } \\
\text { width, m }\end{array}$ & $\begin{array}{l}\text { Based on the thickness of sandbodies defined as a single } \\
\text { and untruncated story }\end{array}$ & $\begin{array}{l}\text { Difficult to find single and } \\
\text { untruncated stories }\end{array}$ \\
\hline $\begin{array}{l}\text { Leeder (1973) } \\
W_{c}=6.8 \times H_{\max }^{1.54}\end{array}$ & $\begin{array}{l}W_{c}: \text { Bankfull } \\
\text { channel width, } \\
\text { m } \\
H_{\text {max }}: \text { Bankfull } \\
\text { channel depth, } \\
\text { m }\end{array}$ & $\begin{array}{l}\text { Bankfull depth: max vertical distance between point bar } \\
\text { and channel thalweg }\end{array}$ & $\begin{array}{l}\text { Upward fining trend is not } \\
\text { representative of point-bar } \\
\text { thickness due to erosion }\end{array}$ \\
\hline $\begin{array}{l}\text { Williams }(1986) \\
W_{c}=21.3 \times H_{\text {mean }}^{1.45}\end{array}$ & $\begin{array}{l}H_{\text {mean }}: \text { Mean } \\
\text { bankfull } \\
\text { channel depth, } \\
\mathrm{m} \\
W_{c}: \text { Bankfull } \\
\text { channel width, } \\
\mathrm{m}\end{array}$ & $\begin{array}{l}\text { Bankfull mean depth computed based on three cross } \\
\text { section in field and topographic maps }\end{array}$ & $\begin{array}{l}\text { No explanation on how these } \\
\text { parameters can be measured in } \\
\text { a fluvial reservoir }\end{array}$ \\
\hline $\begin{array}{l}\text { Collinson (1977) } \\
W_{\mathrm{mb}}=64.6 \times H_{\max }^{1.54}\end{array}$ & $\begin{array}{l}W_{\mathrm{mb}}: \text { Meander } \\
\text { belt width } \\
H_{\max }: \text { Bankfull } \\
\text { channel depth, } \\
\text { m }\end{array}$ & - & $\begin{array}{l}\text { Upward fining trend is not } \\
\text { representative of point-bar } \\
\text { thickness due to erosion }\end{array}$ \\
\hline $\begin{array}{l}\text { Lorenz et al. }(1985) \\
W_{c}=6.8 \times H_{\max }^{1.54} \\
W_{\mathrm{mb}}=4.77 \times W_{c}^{1.01}\end{array}$ & $\begin{array}{l}W_{c}: \text { Bankfull } \\
\text { channel width, } \\
\mathrm{m} \\
H_{\max }: \text { Bankfull } \\
\text { channel depth, } \\
\mathrm{m} \\
W_{\mathrm{mb}}: \text { Meander } \\
\text { belt width, m }\end{array}$ & $\begin{array}{l}\text { Bankfull depth: Thickness of the point bars, each upward } \\
\text { fining trend is assumed as a preserved point bar }\end{array}$ & $\begin{array}{l}\text { Upward fining trend is not } \\
\text { representative of point-bar } \\
\text { thickness due to erosion }\end{array}$ \\
\hline $\begin{array}{l}\text { Fielding and Crane }(1987) \\
H_{\mathrm{max}}=0.55 \times \text { th } \\
W_{\mathrm{cb}}=64.6 \times H_{\mathrm{max}}^{1.54} \\
\text { (channels allowed to } \\
\text { develop full meander } \\
\text { profile) }\end{array}$ & $\begin{array}{l}H_{\max }: \text { Channel } \\
\text { depth, m } \\
\text { th: Sandstone- } \\
\text { body } \\
\text { thickness, m } \\
W_{\mathrm{cb}}: \text { Channel } \\
\text { belt width }\end{array}$ & $\begin{array}{l}\text { Identification of channel is based on their upward fining } \\
\text { profile, and th }<2 \mathrm{~m} \text { is considered as non-channel, } \\
\text { crevasse splays deposition }\end{array}$ & $\begin{array}{l}\text { Estimation of channel depth is } \\
\text { difficult due to erosion and } \\
\text { accretion }\end{array}$ \\
\hline
\end{tabular}

The first three equations describe the relation between bankfull channel depth (maximum or mean) and the width of fluvial channels. The remainder of the equations show empirical relations between width of meander or channel belt and channel bankfull depth (the geometrical parameters are depicted in Fig. 1)

(width) of fluvial channels based on their depths. The parameters are described schematically in Fig. 1.

As pointed out by Miall (2014), the rate and style of avulsion are both important factors affecting mid-range heterogeneities and architecture of fluvial depositions, which are the focus of the present paper. Avulsion occurs at two distinct scales: regional and local. The impact of avulsion rate and its style is investigated by varying aggradation rate and regional avulsion rate.

The local avulsion rate is kept constant due to its relatively limited impact on the overall architecture. In the present paper, it is assumed that sedimentation is controlled by only a few important factors, namely avulsion frequency, floodplain aggradation rate, and the ratio of 

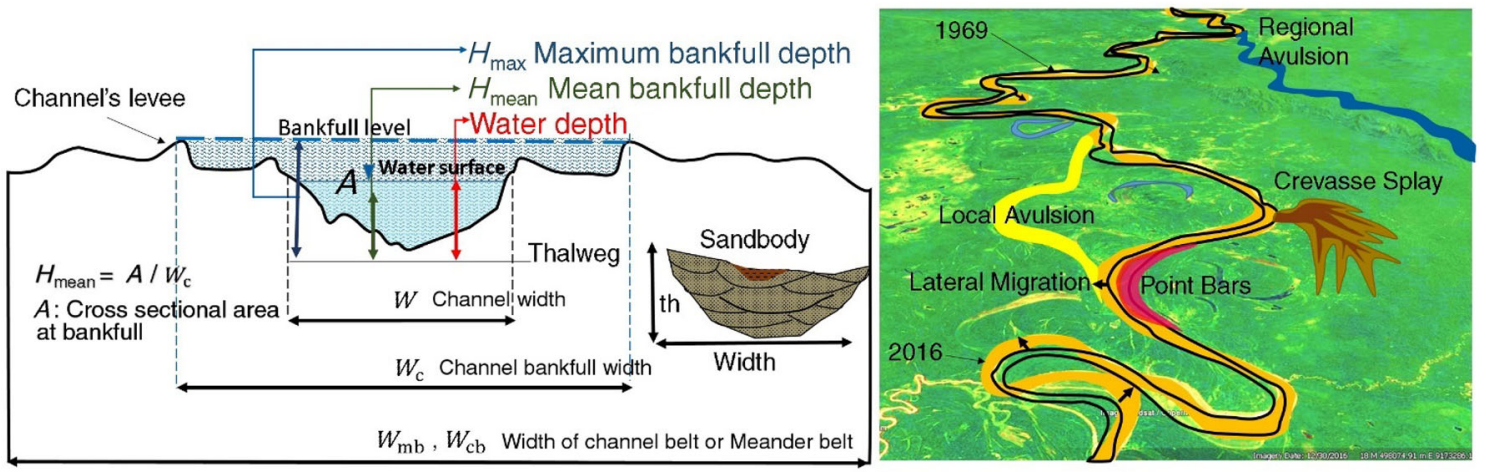

Fig. 1 Schematic demonstration of channel geometry and the relevant geometrical parameters. The left panel shows a cross section of flow and the geometrical parameters of the fluvial channel. In the right panel, Ucayali River (Rio Ucayali) in Peru is used as an example to

channel belt or of floodplain to the width in the stacking of channel bodies.

Avulsion controls the reoccupancy of channel belts, stacking and distribution of sandbodies and serves as a primary factor in shaping the architecture of fluvial depositions (Jones and Schumm 1999; Miall 2014; Slingerland and Smith 2004). Figure 2 shows the impact of the rate of aggradation, bank migration, and avulsion on the shape and connectivity of sandbodies. The focus of the present research is on the role of avulsion frequency (Av), channel bankfull depth $\left(H_{\max }\right)$, and shape of channels (presented by different relationships between channel width and water depth) in the architecture of reservoirs. show channel migration (1969 shown by solid black lines, and 2016 shown by orange). Point bars, crevasse splay, and two hypothetical paths for regional (dark blue path) and local avulsion (purple path) are schematically presented

\subsection{Geological modeling}

Process-based simulators generate complex models that cannot be easily conditioned with the available data; therefore, process-based simulators are rarely used directly to generate subsurface models (Karssenberg et al. 2001). Process-imitating models are simplified process-based simulators that only consider the most significant processbased factors, therefore requiring fewer parameters (Koneshloo et al. 2017). Process-imitating software, FLUMY, is used as a proxy for process-based simulators. This package, developed at MINES ParisTech (Centre de Géosciences in Fontainebleau, France), generates realistic models for fluvial meandering systems (Deviese 2010; Lopez et al. 2009), by tracking the evolution of meandering channels. The list of the model's parameters is provided in Table 2. FLUMY makes use of a limited number of key
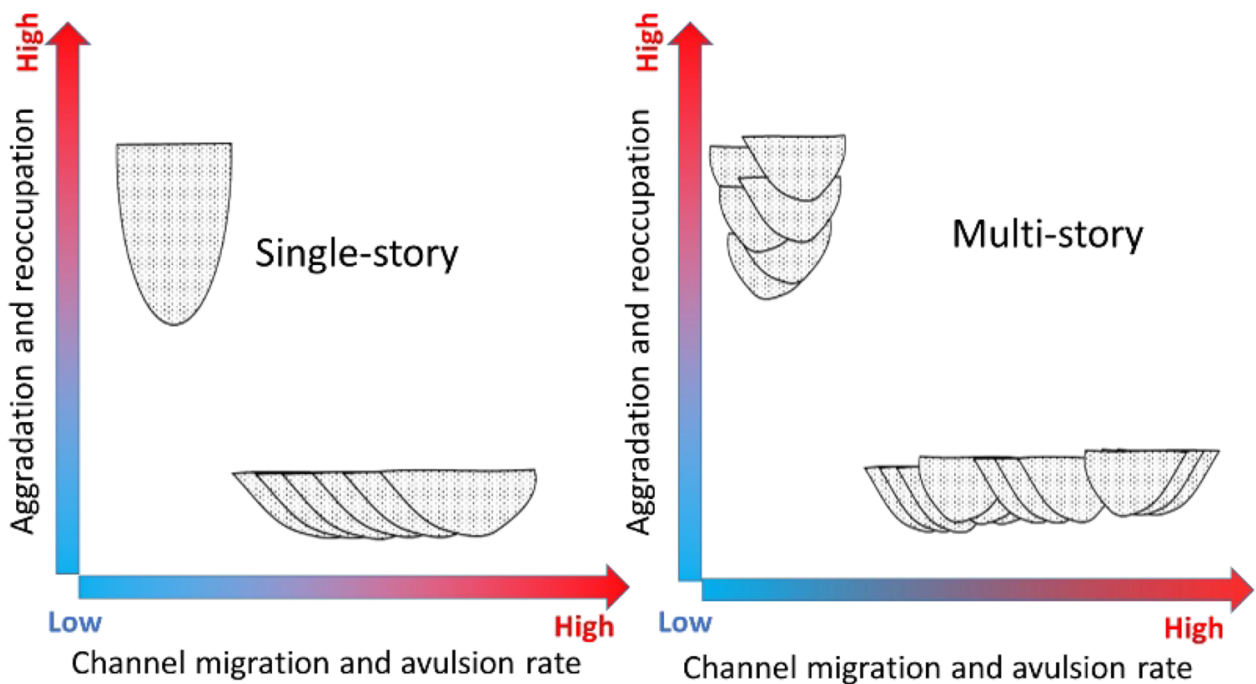

Fig. 2 Role of geological factors controlling the connectivity and the shape of deposited sandbodies. (Reproduced with permission from Gibling 2006) 
Table 2 Parameter set used in FLUMY to generate geological models

\begin{tabular}{lll}
\hline Parameter, unit & Default value & Value used for modeling \\
\hline Channel bankfull width, $\mathrm{m}$ & 100 & $\begin{array}{c}\text { Based on the relationship used and its } \\
\text { maximum depth }\end{array}$ \\
Maximum bankfull depth, m & $1 / 10$ of channel width & $2.0 ; 2.5 ; 3.0 ; 3.3 ; 3.5 ; 3.7 ; 4.0$ \\
Mean bankfull depth & $\begin{array}{c}2 / 3 \text { of maximum depth for parabolic } \\
\text { cross section }\end{array}$ & $\begin{array}{c}2 / \pi \text { of maximum depth for ellipse shape } \\
\text { section }\end{array}$ \\
Bank erodibility coefficient (based on channel & $4 \times 10^{-8}$ & $6.5 \times 10^{-8}$ \\
migration in m/s) & & $1 \times 10^{4} ; 4 \times 10^{4} ; 7 \times 10^{4}$ \\
Regional avulsion, year & Type: Periodic period $=2200$ & Default \\
Local avulsion or levee breach, year & Type: Periodic period $=600$ & Default \\
Probability of transition from CSI to CSII & 0.9 & Default \\
Aggradation, year & Type: Periodic period $=100$ & 2000 \\
Thickness exponential decrease, $\mathrm{m}$ & 1000 & 2000 \\
Grain size exponential decrease, $\mathrm{m}$ & 1000 & Default \\
Levee width (multiple of the channel width) & 6 & Default \\
Slope along flow direction & $1 \times 10^{-3}$ &
\end{tabular}

parameters (fewer than what is needed for a process-based model). The main controlling factors are regional avulsion rate, aggradation rate, and general topography (slope of the basin). In each iteration, FLUMY calculates migration of the centerline; details are described in Cojan et al. (2005) and Lopez et al. (2009). For each pixel, sediment will be deposited according to its distance from the centerline. An exponential function for distance from the centerline is used to assign the grain size and the thickness of the sediments during each iteration (Lauer and Parker 2008; Pizzuto et al. 2008).

In FLUMY, regional avulsion is defined as an avulsion happening upstream of the domain and local avulsion refers to a levee breach inside the domain. The frequency of the local avulsion (levee breaches) and regional avulsion, and the aggradation rate of the floodplain used in this study are specified Table 2 . Other variables include the equation used to relate channel width to channel depth, avulsion periodicity (Av), and maximum channel depth $\left(H_{\max }\right)$.

A 3D model of a fluvial meandering system with approximately 7 million cells $(216 \times 216 \times 150)$ is simulated. This simulated field is $75 \mathrm{~m}$ thick, $3240 \mathrm{~m}$ wide, and $3240 \mathrm{~m}$ long and is used as the reference model. Cell dimensions are $0.5 \mathrm{~m}$ in the $\mathrm{z}$-direction and $15 \mathrm{~m}$ in the $x$ and $y$-directions. There are two possible sources of randomness in FLUMY.

The first source is the randomness of the model's parameters, and the second source resides in the way the algorithm has been designed to simulate the fluvial regime, initial river path, and its new path caused by regional avulsion. Parameters used in the generation of the reference model are based on unit four of Schooner Field, as reported by Deviese (2010). Lithological data are sampled along 16 vertical wells located approximately at centers of 80 -acre parcels in the reference model. Subsequently, fifty-four geological models are generated using FLUMY, by varying the maximum depth of the fluvial channel, the equation used to estimate channel widths, and the avulsion rate.

Figure 3 shows the width of channels calculated using the first three equations in Table 1. As shown in Fig. 4, William's formula generates a larger fluvial channel, and Bridge and Mackey's formula leads to a narrower channel. To generate a 3D model of the facies, data are sampled every $0.5 \mathrm{~m}$ vertically and lithotypes are grouped together under three main facies: coarse sediments (SS), which are common deposit bars in fluvial channels; crevasse splays (CS), which are finer sands adjacent to main channel

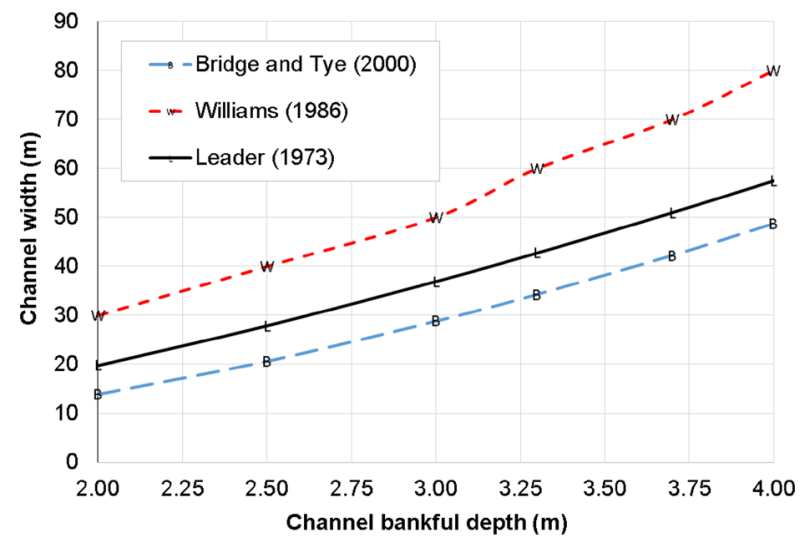

Fig. 3 Relation between maximum depth of meandering channels and their width 

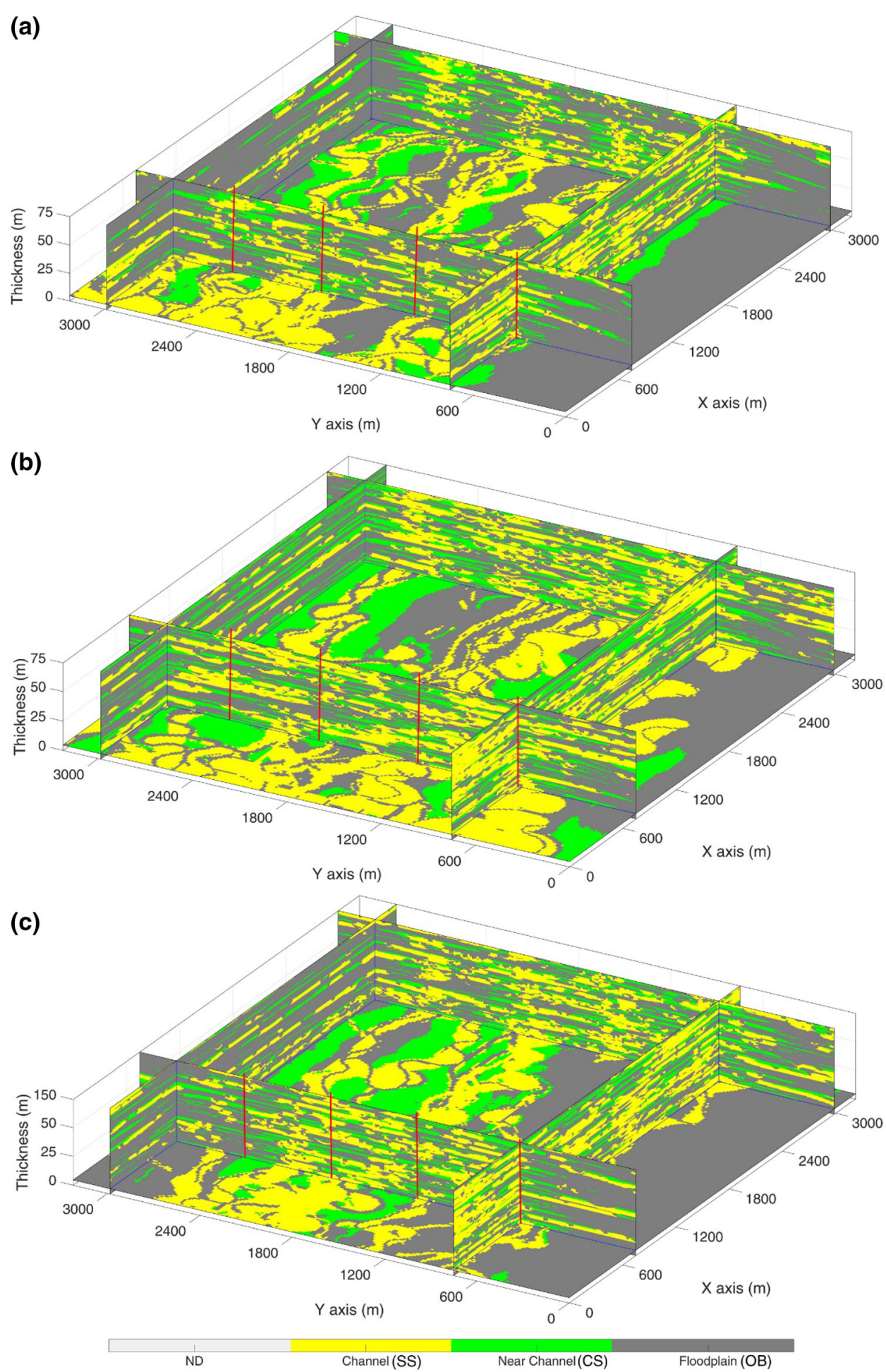

Fig. 4 Cross section of the fluvial system generated based on a Eq. 1: Bridge and Tye (2000), b Eq. 2: Williams (1986), and c Eq. 3: Leeder (1973)

deposits; and overbank deposits (OB), which are usually floodplain muds. The preservation potential of each geological feature is a crucial point in fluvial reservoir modeling. As shown in Figs. 4 and 5, attempts to use current geomorphologic data to define the objects' geometry and collocation often lead to an incorrect subsurface model (Pyrcz and Deutsch 2014). Preferential paths (highly permeable facies) are not sinusoidal channels, but a complex 

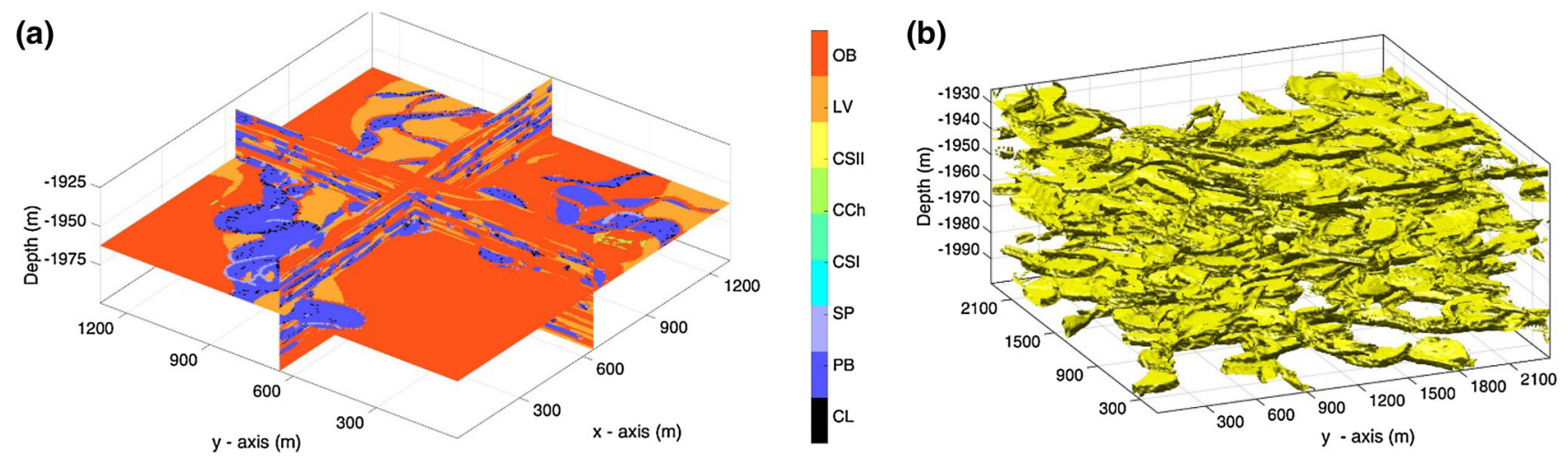

Fig. 5 a 3D view of the reference geological model (realization), b sediments having a permeability more than $1 \mathrm{mD}$

aggregation of lobe-shaped sediments (Fig. 5b). Sixtythree static models were generated and primary oil production simulated for each realization.

\subsection{Petrophysical modeling}

Porosity and permeability control the flow and fluid storage capacity of a reservoir and are largely determined by lithology and grain size, sorting, and consolidation (Slatt 2006). Porosity values are simulated independently for each facies using sequential Gaussian simulation using parameters shown in Table 3. A cookie-cutter approach (Mao and Journel 1999), shown schematically in Fig. 6, is used to generate the porosity model for each case. Permeability $(k)$ is calculated based on the porosity value $(\varphi)$ and the type of facies (represented by their grain size, $d_{\mu \mathrm{m}}$ ), using the Kozeny-Carman equation (Mao and Journel 1999). Tortuosity is assumed to be 2.5 (Mao and Journel 1999), and pore diameter (in $\mu \mathrm{m}$ ) is defined as a function of facies type. This work assumes that pore sizes are proportional to grain sizes following a cubic packing form where pore diameters are $47 \%$ of grain diameters. Then a random noise with a mean of 0.0 and a standard deviation of 0.5 is added to the logarithmic value of calculated $k$, as

$k=\frac{1}{180} \frac{\varphi^{3}}{(1-\varphi)^{2}} d_{\mu \mathrm{m}}^{2}+$ noise

Table 3 Variogram models used to generate porosity values
Figure 7 shows the histogram and scatter plot of porosity and permeability values of the facies in the reference model. The mean and standard deviation of porosity for each facies are based on Rocky Ridge field in North Dakota (Hastings 1990) and Byrnes's study on low-permeability sandstones in the Rocky Mountains (Byrnes 1997). To ensure reasonable simulation times, the generated static models are upscaled. Porosity and permeability are upscaled using arithmetic and geometric averaging, respectively (Jensen 1991). Figure 8 shows fine-scale and upscaled reference model.

\subsection{Reservoir modeling}

Fluid properties are shown in Table 4. The reservoir is assumed to be part of a larger field; therefore, the boundaries of the model are considered open boundaries. Relative permeability relations are assumed to be sole functions of local saturation (Ren et al. 2017). As the type of facies, and their porosity and absolute permeability values vary within the reservoir, the irreducible water and oil saturations vary as well. Thus, three different rock regions are defined based on the facies. Relative permeability and capillary pressure relations are assigned to each facies (Fig. 9). Three different datasets are used for theses facies: sandstone, tight sand, and shale rock reservoirs. The main reasoning behind

\begin{tabular}{llll}
\hline Parameters & Facies & & \\
\cline { 2 - 4 } & Sandstones (SS) & Crevasse splays (CS) & Overbank deposits (OB) \\
\hline Nugget & $1 \%$ & $1 \%$ & $1 \%$ \\
Type & Spherical & Spherical & Spherical \\
Ranges, m & $1000,500,10$ & $500,200,5$ & $750,750,7$ \\
Angles & $90,0,0$ (flow direction) & $90,0,0$ (flow direction) & $0,0,0$ \\
Average & 0.16 & 0.10 & 0.06 \\
Standard deviation & 0.025 & 0.025 & 0.020 \\
\hline
\end{tabular}




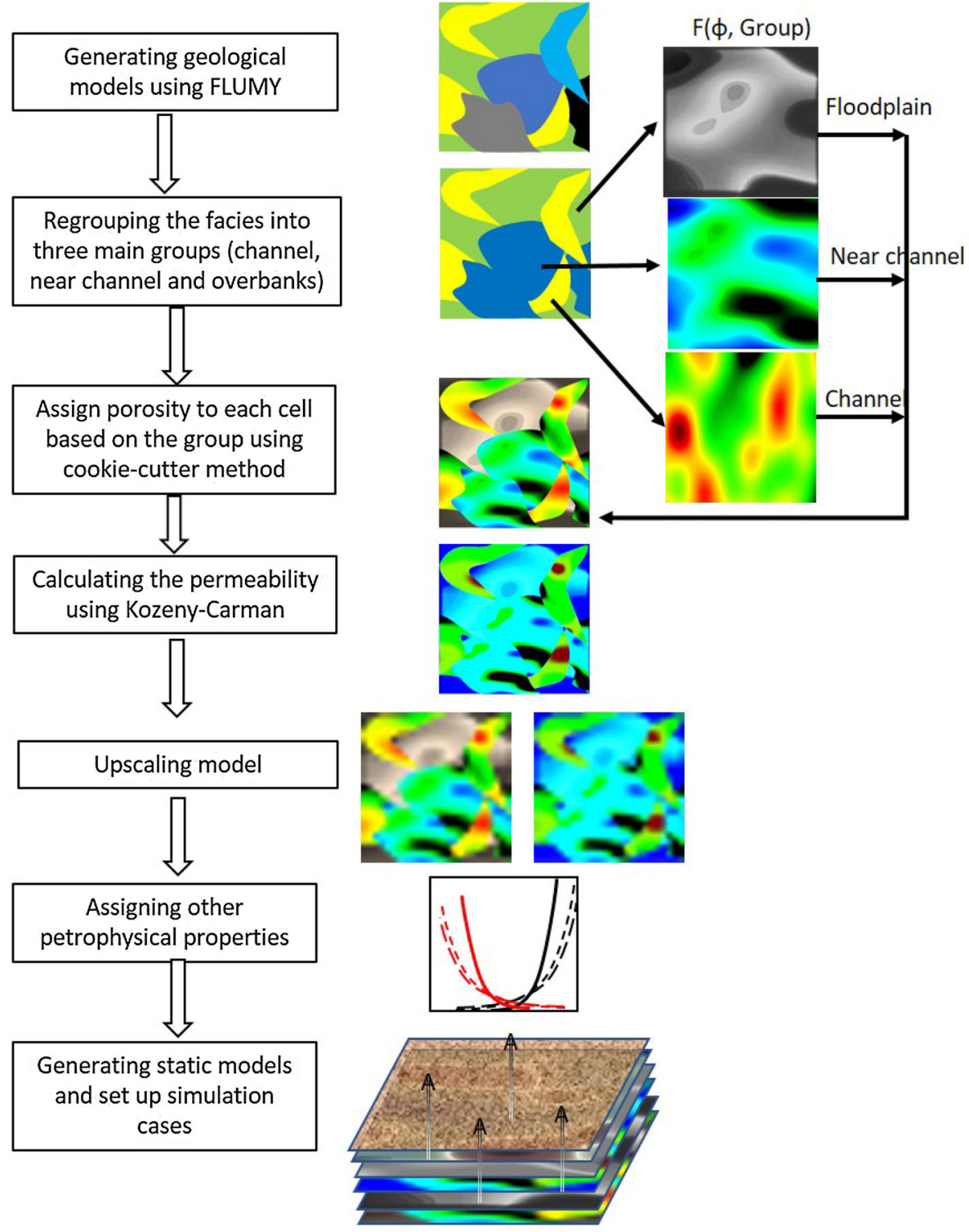

Fig. 6 Workflow used to generate static models (realizations)

this choice is the similarity between the facies and their lithology. For sandstones, the data from the Rocky Ridge field in North Dakota are used (Hastings 1990). As crevasse splays are often considered non-reservoir rock, only few measurements of their relative permeability and capillary pressure relations are available (e.g., Ramon and Cross 1997). This can be explained by the fact that crevasse splays facies are a small proportion of fluvial reservoirs. In addition, they represent low-quality reservoirs due to the inclined mud drapes forming barriers to both vertical and horizontal flows. In this study, the data from a tight formation in Canada (Zhang et al. 2012) have been used for crevasse splays.

Overbank groups (including wetlands, mud plugs, and overbank) are assumed to be fine silt to clay, which are similar to typical shale formations; therefore, for overbanks, constitutive relations are based on published experimental data from the Bakken reservoir's organic-rich Bakken shale (Nojabaei et al. 2014).

A streamline-based flow simulator, studioSL ${ }^{\circledR}$ from StreamSim, is used for fluid flow simulation due to its low computational cost relative to traditional reservoir simulators (Thiele et al. 1997). All wells are assumed to start producing at the same time with the same pressure control.

\section{Results and discussion}

Field-level and well-level simulation results are presented and discussed to examine the impact of global and local similarities. The relation between NGR and oil production, 

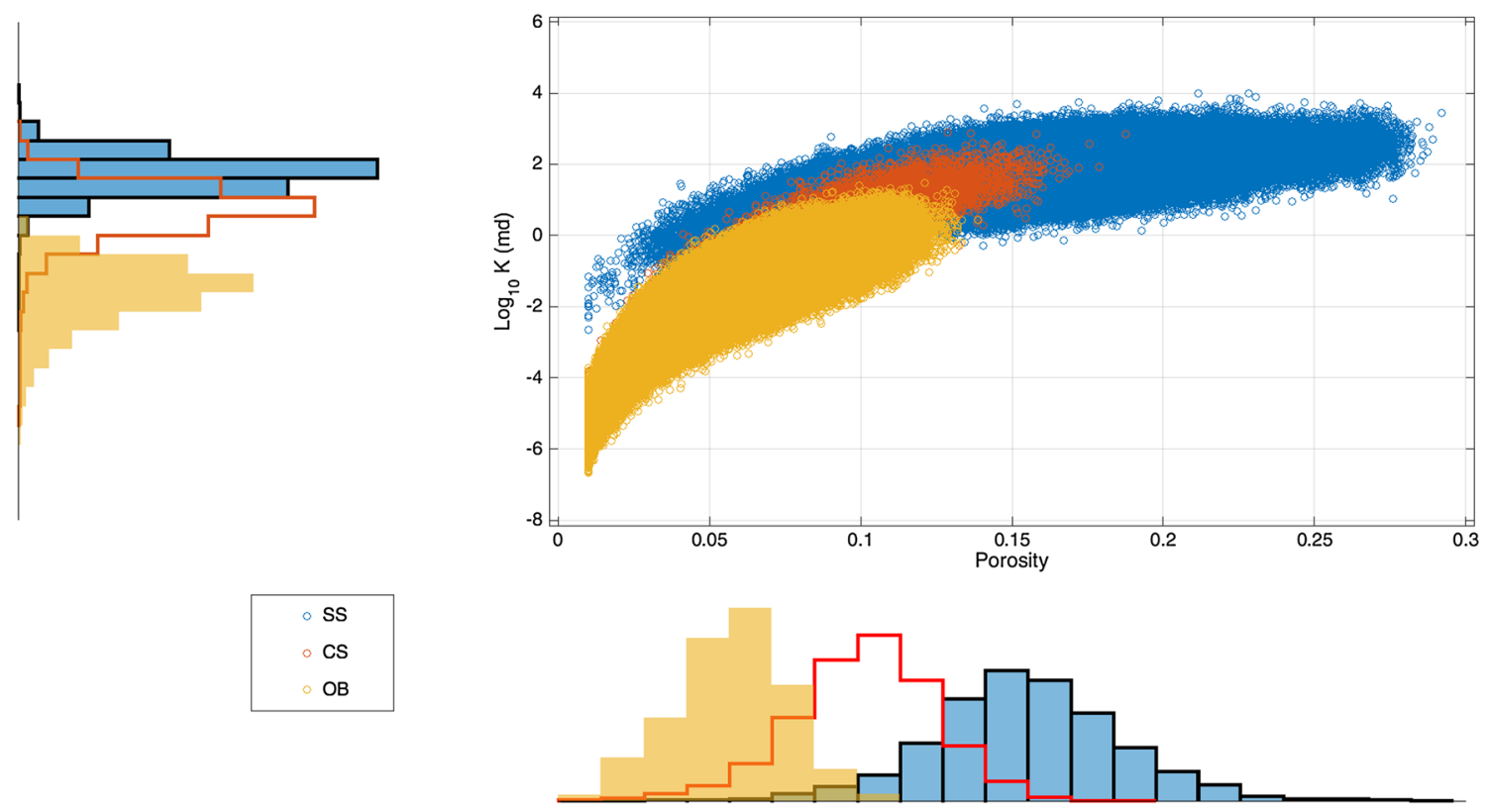

Fig. 7 Distribution of porosity and permeability for each category and their relationship

(a)

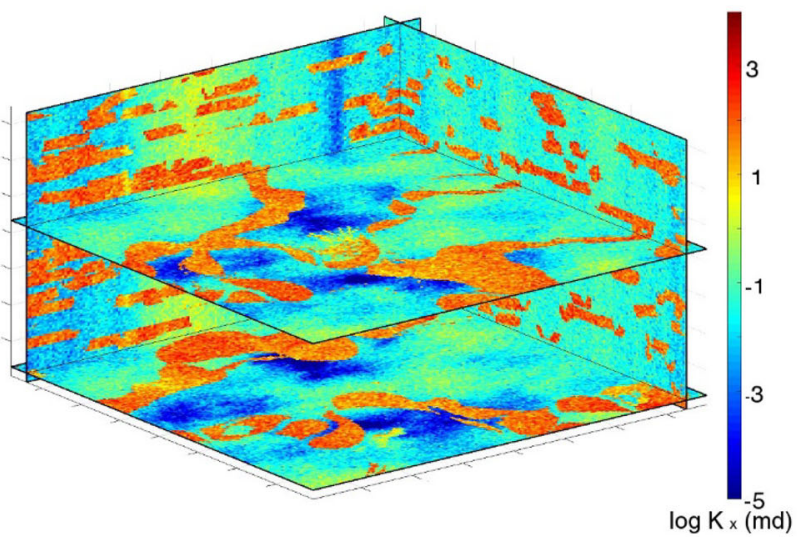

(c)

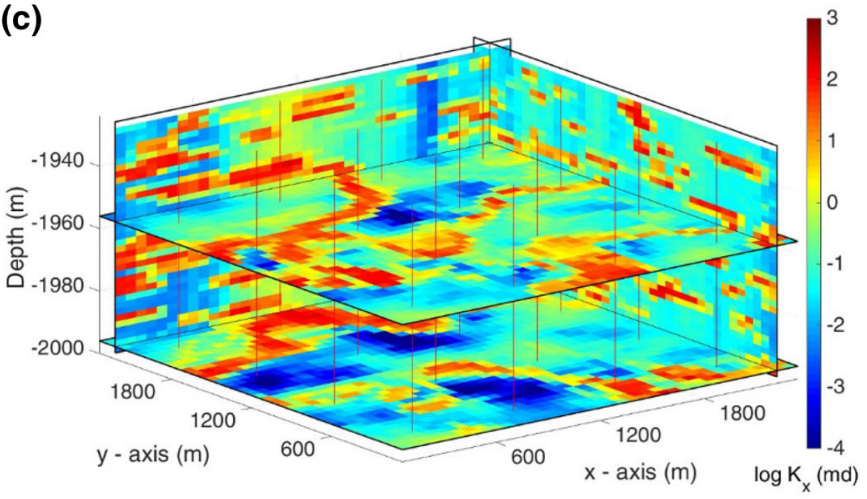

(b)

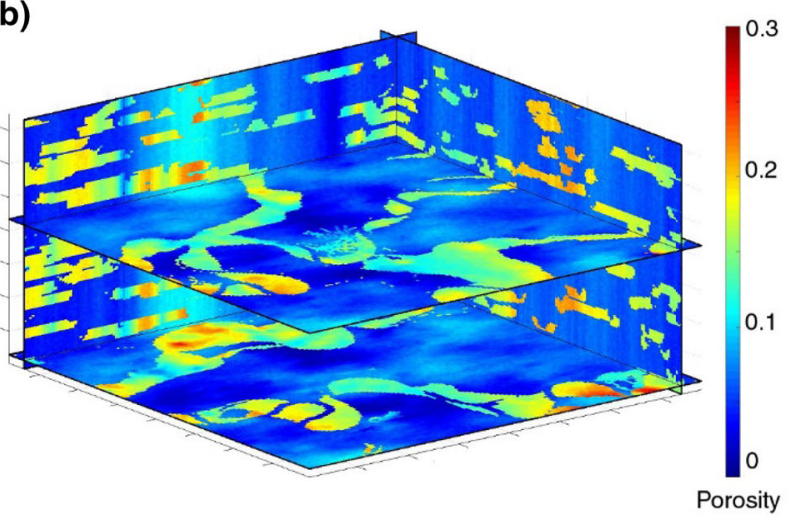

(d)

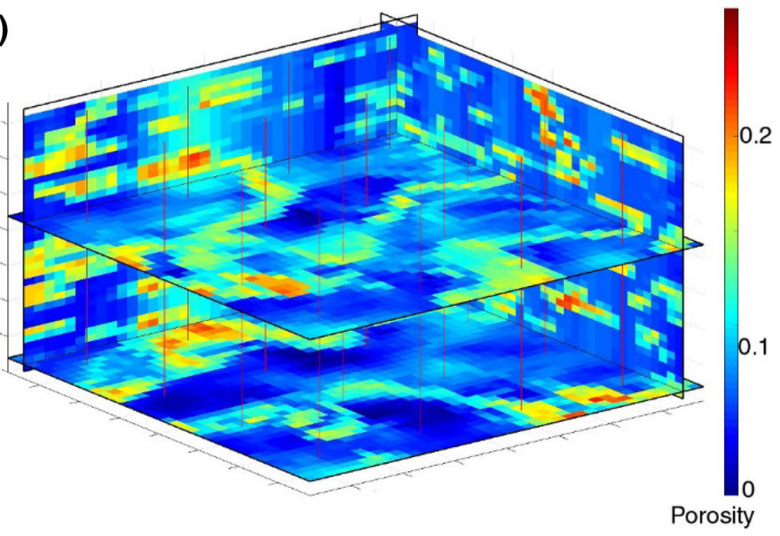

Fig. 8 Three-dimensional view of resulting a permeability, b porosity for the reference model (realization), and upscaled results of c permeability and $\mathbf{d}$ porosity 
Table 4 Reservoir and fluid properties

\begin{tabular}{lll}
\hline Properties & Value & Unit \\
\hline Model size & $2340 \times 2340 \times 74$ & $\mathrm{~m}$ \\
Grid size & $60 \times 60 \times 2$ & $\mathrm{~m}$ \\
Reservoir thickness & 74 & $\mathrm{~m}$ \\
Number of layers & 37 & - \\
Top of reservoir & 1926 & $\mathrm{~m}$ \\
Initial reservoir pressure & 22 & $\mathrm{MPa}$ \\
$K_{z} / K_{x}$ & 0.1 & - \\
Density (oil, water, and gas) & $720.8,1009.5,1.12$ & $\mathrm{~kg} / \mathrm{m}^{3}$ \\
Rock compressibility & 4.35 & $1 / \mathrm{MPa}$ \\
Primary production period & 450 & $\mathrm{days}$ \\
Minimum economic oil rate & 10 & $\mathrm{bbl}$ \\
Bottom hole pressure & 19.3 & $\mathrm{MPa}$ \\
\hline
\end{tabular}

and the impact of model parameters on NGR and production values are discussed.

\subsection{Controlling factors and net-to-gross ratio}

A regression study was carried out to illustrate the relation between controlling geological factors and NGR. The NGR for each realization has been estimated for the aggregate of all cases (Fig. 10a) and the data generated using each equation separately (Fig. 10b) using multiple linear regression. The statistical significance of the regression is represented by its $p$ value, which is the probability of being extreme considering the null hypothesis (Utts and Heckard 2011). The coefficients of the regression are provided in Table 5. The overall regression for the aggregate scenario has a coefficient of determination of 0.71 . Channel depths are statistically significant $\left(P=8 \times 10^{-11}\right)$, while avulsion periodicity is not significant $(P=0.42)$. The coefficient of determination for each dataset, considered separately, is larger than 0.94, and the statistical significance of avulsion periodicity decreases as the width-to-depth ratio increases.

The results indicate that the depth-to-width ratio influences the ultimate NGR significantly (wider channels with the same depth are more likely to deposit larger sandbodies), see Fig. 11. Cumulative production for all models is shown in Fig. 12. Compared to equations proposed by Leeder, and Bridge and Tye, the use of Williams's equation (Table 2) results in larger channels and more oil production. A higher avulsion periodicity leads to a longer channel residence time in its bed. As a result, point bars are laterally more extended and avulsion controls the architecture of fluvial reservoirs as point bars are the main preserved sandbodies in meandering fluvial systems. In such cases, the number of individual channels decreases and a higher Av does not always result in higher cumulative production. Among all cases with the same fluvial channel geometry, the majority of the realizations with an Av value of 40,000 years (the average of Av values of all cases; shown in red) result in higher cumulative oil production values, see Fig. 12. The impact of local heterogeneity is shown in Fig. 13, where the rate of oil production in the most productive well (W05) is at least one order of magnitude higher than the rate of the least productive well (W16). Figure 13 shows a distinct difference in production from one well to another; moving eastward from W05 to W09, total production drops considerably (from 8600 to $1300 \mathrm{~m}^{3}$ ). This rapid change in production indicates that productive rocks are distributed heterogeneously in the reservoir with a scale less than that of the well spacing.
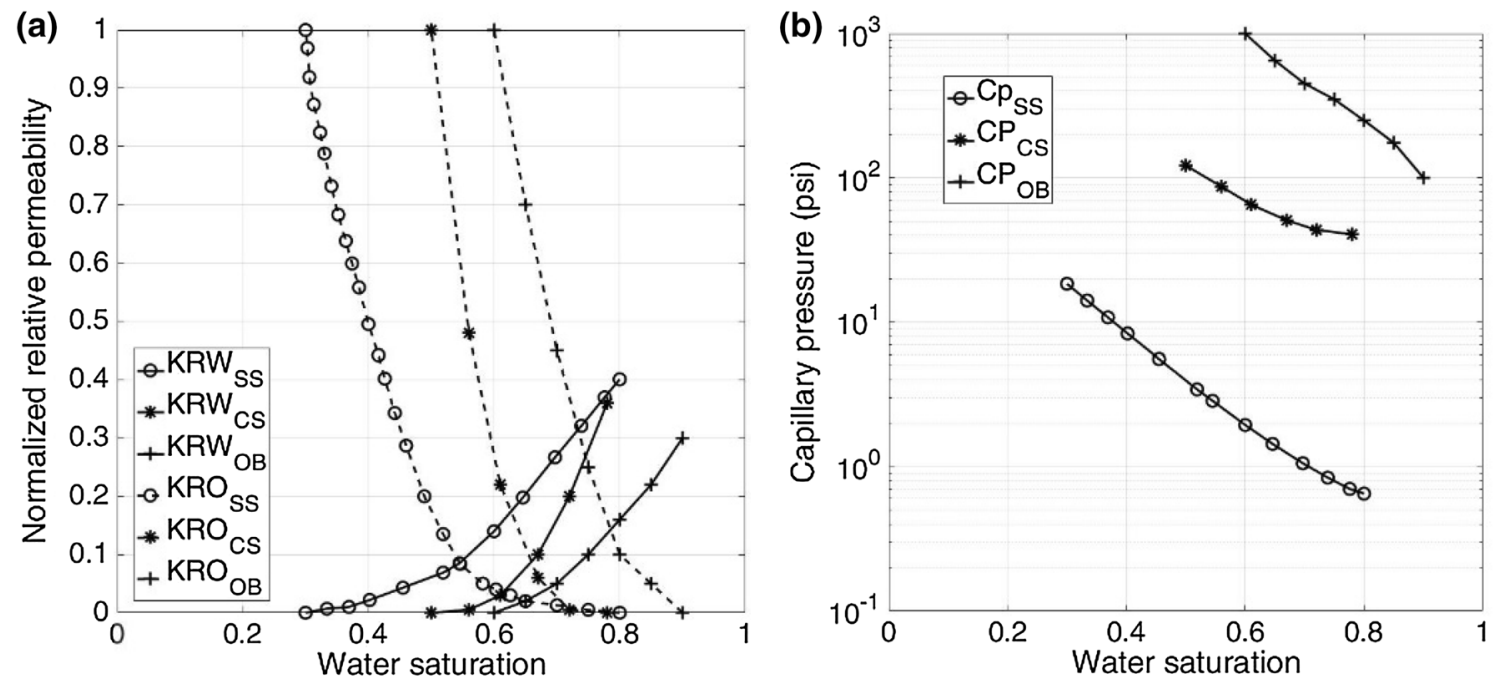

Fig. 9 a Relative permeability curves and $\mathbf{b}$ capillary pressure curves for the three facies 


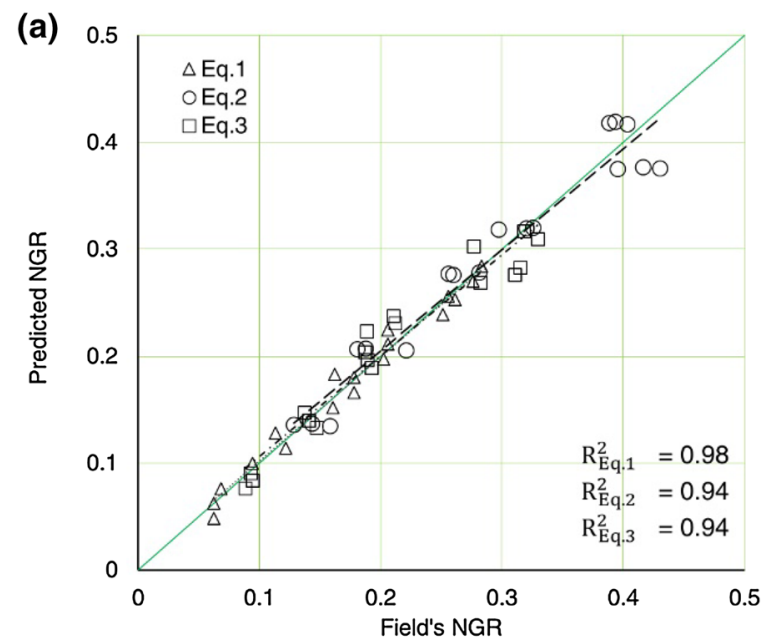

Fig. 10 Comparison between estimated NGRs and real NGRs. NGRs are estimated based on fluvial channels' depth and their regional avulsion periodicity. Estimation of NGR using multivariate linear

Table 5 Coefficients of regression for NGR using channel depth and avulsion rate for all realizations

\begin{tabular}{lllll}
\hline Variables & Eq. 1 & Eq. 2 & Eq. 3 & All \\
\hline Channel depth & $\mathbf{1 . 0 4 E}-\mathbf{0 1}$ & $\mathbf{1 . 4 1 E}-\mathbf{0 1}$ & $\mathbf{1 . 1 3 E}-\mathbf{0 1}$ & $\mathbf{1 . 1 9 E}-\mathbf{0 1}$ \\
Avulsion rate & $\mathbf{4 . 7 0 E}-\mathbf{0 7}$ & $3.30 \mathrm{E}-08$ & $2.37 \mathrm{E}-07$ & $2.47 \mathrm{E}-07$ \\
\hline
\end{tabular}

Bold values are statistically significant $(\alpha=0.05)$

The interactions of the geometric factors with avulsion frequency are not statistically significant (as shown in Table 5). Although Bryant et al. (1995) have shown that

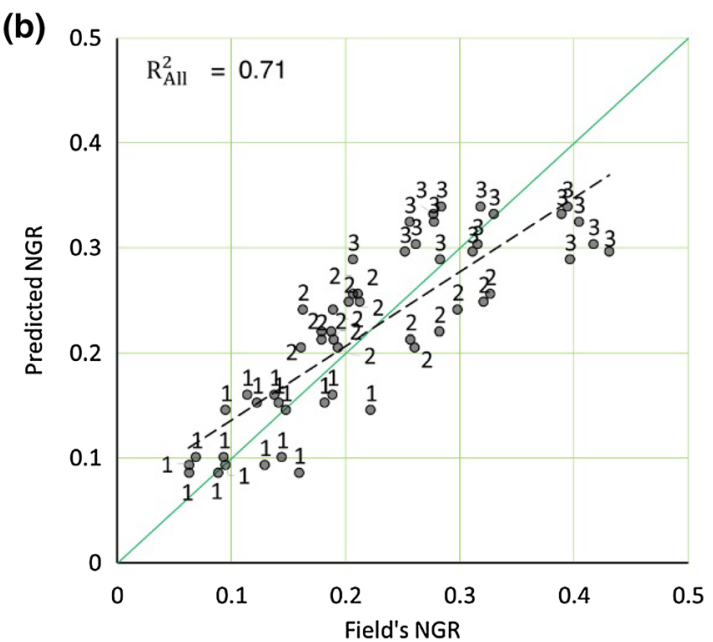

regression was performed $\mathbf{a}$ using all data and $\mathbf{b}$ separately for each group. Dashed line represents the ideal estimator, and the number on a represents the equation number

avulsion rate is closely correlated with sediment feed rate, it is rather impractical to describe the interaction between geometric factors and avulsion quantitatively. Similar to the approach used by Comunian et al. (2014), geometric factors and avulsion are assumed to be independent to simplify the analysis. A higher avulsion periodicity does not necessarily lead to a higher NGR and thus a higher cumulative production.

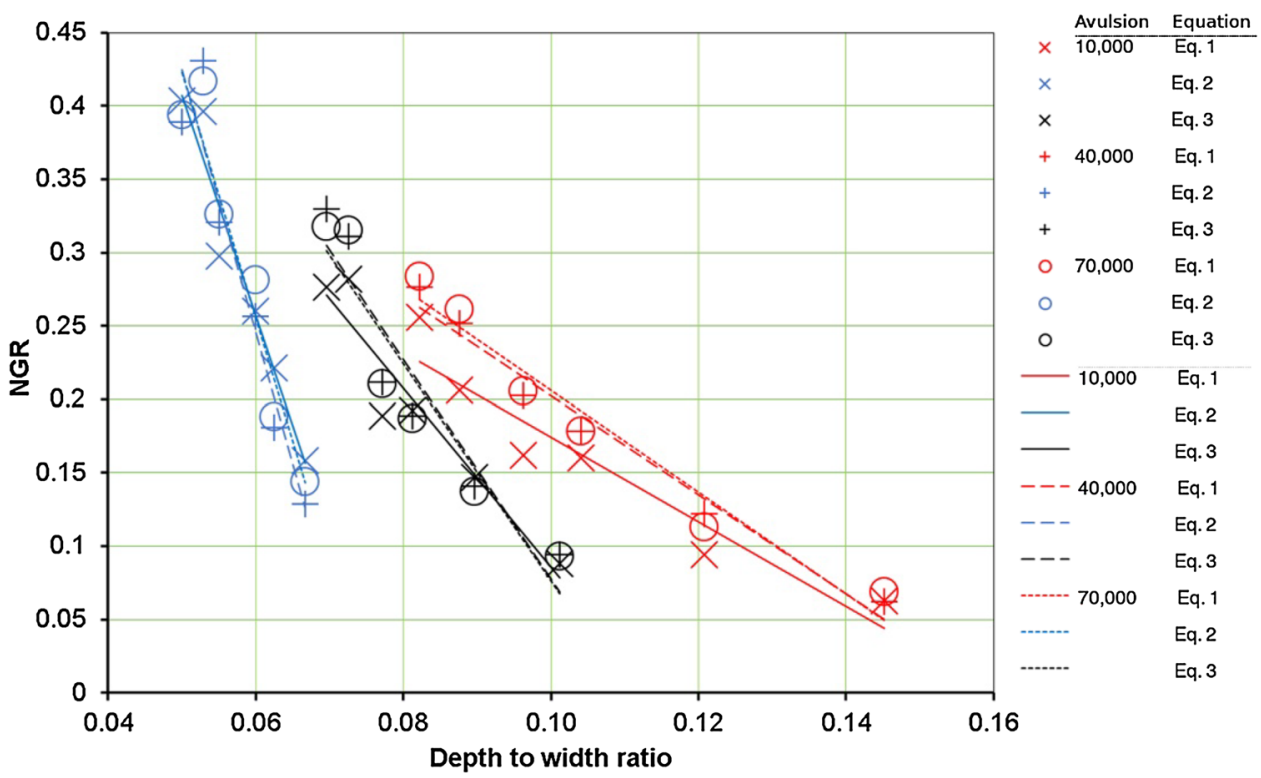

Fig. 11 Relation between NGR and fluvial channel's depth-to-width ratio-color has been used to show cases based on a single equation. As can be seen in this figure, the variation caused by the geometry of channels $(\mathrm{D} / \mathrm{W})$ is more important than by the avulsion rate 

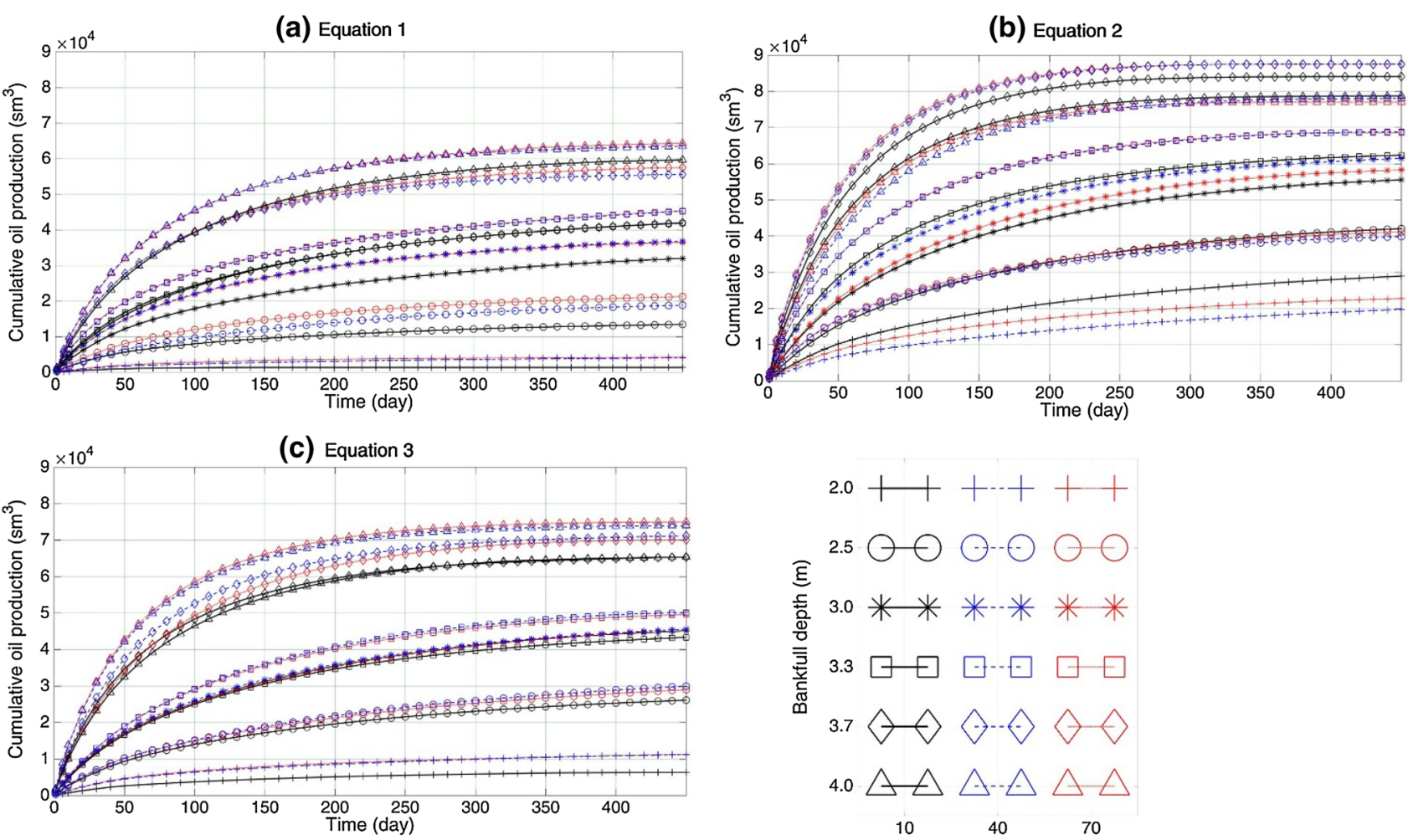

$\begin{array}{lll}10 & 40 & 70\end{array}$

Avulsion rate (Thousands year)

Fig. 12 Cumulative oil production curves; a realizations based on Eq. 1, b realizations based on Eq. 2, and $\mathbf{c}$ realizations based on Eq. 3

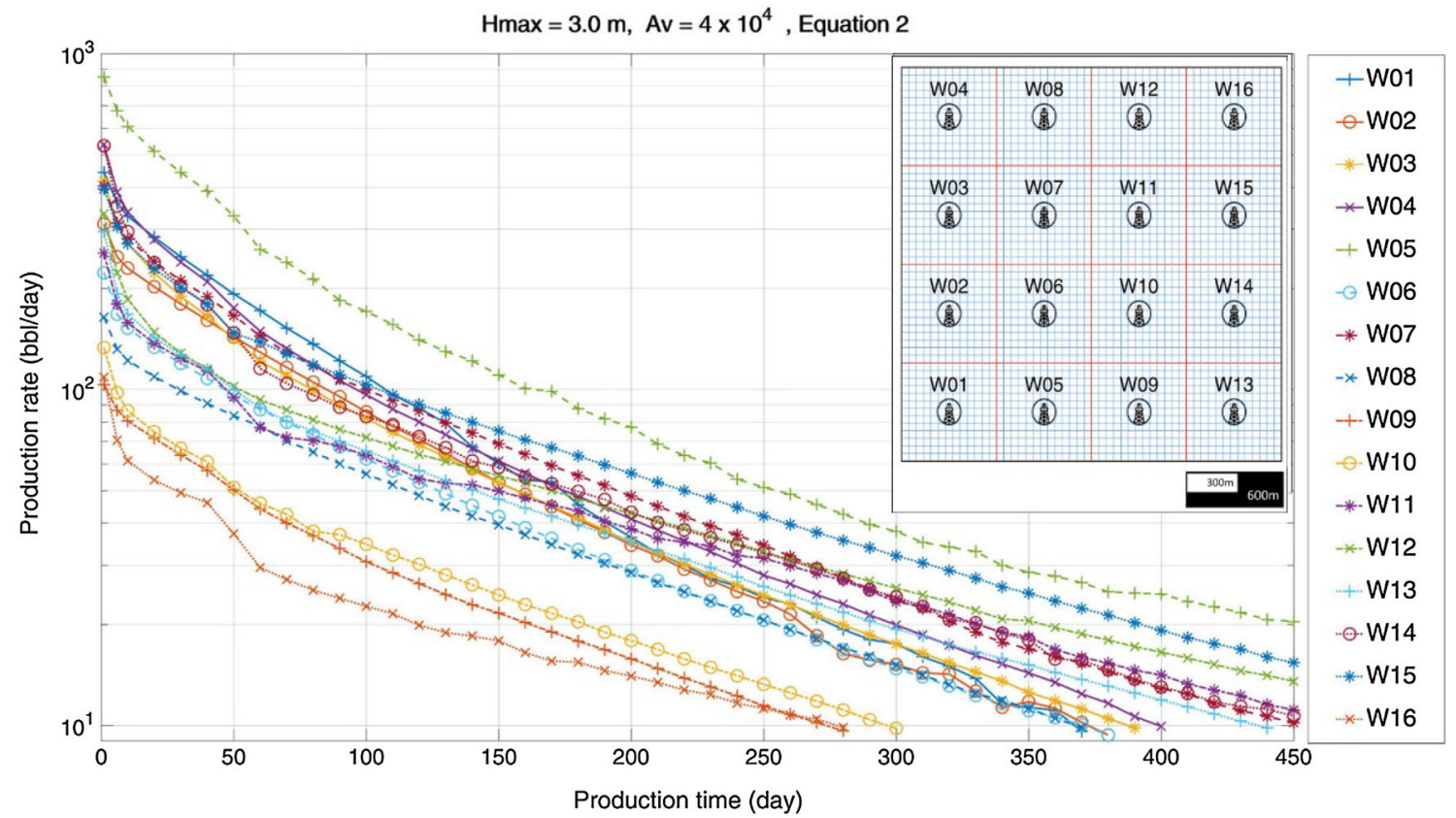

Fig. 13 Oil production rate from sixteen wells for the reference model (realization) 

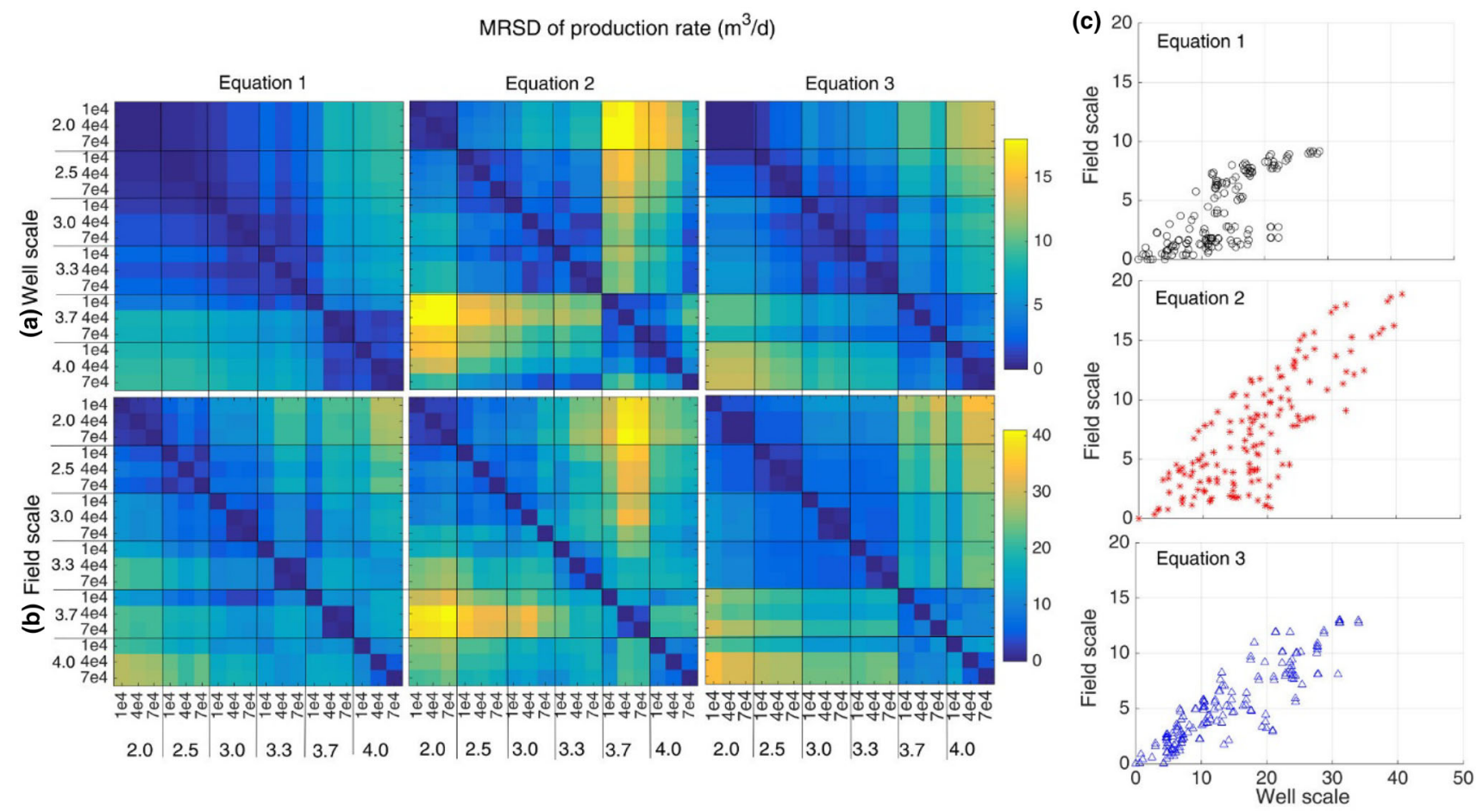

Fig. 14 Dissimilarity distances of realizations at a well level and b field level using the mean root-square distance (MRSD) in their rate of oil production along with all timesteps in three classes according to

\subsection{Similarity of field-level cumulative production}

In the previous section, we analyzed the relation between cumulative oil production and $H_{\max }, \mathrm{Av}$, and the equation that describes the geometry of the fluvial channels. In this section, that relation is investigated using the absolute difference in the cumulative production of the realizations to define a distance metric. As shown in Fig. 14, entries on the main diagonal of each distance matrix are equal to zero. As the distance between realizations increases (dissimilarity matrix entries that are further away from its diagonal), the difference between the cumulative production of those realizations increases as well. The production distance matrix for realizations based on Eq 1 (Bridge and Tye-Table 1) exhibits gradual changes near the main diagonal. The distance matrix for realizations based on Eq 2 (Leeder, Table 1) appears to be controlled mainly by the bankfull maximum, $H_{\max }$, whereas in the first group (Eq 1), avulsion rate is also an important factor. The distance matrix for realizations based on Eq 3 (Williams, Table 1) exhibits characteristics between those from the first (Eq 1) and second (Eq 2) matrices. The average cumulative oil production from models with an Av of 10,000 years is approximately 44,800 cubic meter $\left(\mathrm{m}^{3}\right)$, while the average cumulative oil production from models with an Av of 40,000 years (around 46,400 $\mathrm{m}^{3}$ ) is closer to the equation used to estimate the width of the fluvial channel; c Scatter plot of dissimilarity distance of the fields at field level and well level

the results from models with an Av of 70,000 years $\left(48,900 \mathrm{~m}^{3}\right)$. Therefore, production and avulsion frequency do not appear to have a linear relation (see Table 6). A three-way analysis of the variance of the fields' production values suggests that the most important factor is the maximum depth of the fluvial channels followed by the equation used to estimate channel widths and avulsion frequencies (Table 7). While the interaction between the maximum depth of fluvial channels and the equation that is used to calculate their widths is statistically significant, the interactions of the avulsion rate with these parameters are not statistically significant.

\subsection{Similarity of well-level production across realizations}

Differences between well-level production values in each field are mainly due to local variations in geological features in the reservoir. Figure 14 shows the comparison of the patterns of dissimilarity of the realizations at a well level. The dissimilarity is calculated based on the mean root-square distance (MRSD) of well production rates through all timesteps. The realizations based on Eq 1 show gradual changes in the MRSDs of their production rates. This gradual change is observed in the two other groups as well. There is a sharp change in the field-level rate of production between realizations with $H_{\max }$ equal to $3.7 \mathrm{~m}$ 
Table 6 Sensitivity of cumulative production to the main factors

\begin{tabular}{|c|c|c|c|c|c|}
\hline \multirow[t]{2}{*}{ Factor } & \multicolumn{2}{|l|}{ Factor's } & \multicolumn{3}{|c|}{ Average of cumulative production, $\mathrm{m}^{3}$} \\
\hline & Lower band & Upper band & Lower band & All cases & Upper band \\
\hline Avulsion, years & 10,000 & 70,000 & 44,843 & 47,565 & 48,555 \\
\hline Equation & Eq. 1 & Eq. 2 & 36,980 & 47,565 & 60,122 \\
\hline$H_{\max }, \mathrm{m}$ & 2 & 4 & 12,228 & 47,565 & 70,639 \\
\hline
\end{tabular}

Table 7 Factorial analysis of variance of statistically significant interactions on realizations' production

\begin{tabular}{lrlrl}
\hline Source & $d f$ & Mean Sq. & \multicolumn{1}{l}{$F$} & Prob $>F$ \\
\hline$H_{\max }$ & 5 & $3.41 \times 10^{14}$ & 677.19 & $1.4 \times 10^{-21}$ \\
Equation & 2 & $1.78 \times 10^{14}$ & 353.89 & $2.5 \times 10^{-16}$ \\
Avulsion & 2 & $7.21 \times 10^{12}$ & 14.32 & $1.4 \times 10^{-4}$ \\
$H_{\max } \times$ equation & 10 & $3.82 \times 10^{12}$ & 7.58 & $6.8 \times 10^{-5}$ \\
$H_{\max } \times$ avulsion & 10 & $5.93 \times 10^{11}$ & 1.18 & $\mathbf{0 . 3 6 1}$ \\
Equation $\times$ avulsion & 4 & $1.11 \times 10^{12}$ & 2.20 & $\mathbf{0 . 1 0 5}$
\end{tabular}

$d f$ is degree of freedom; Mean Sq. represents the mean square of errors; $F$ is Fisher's criteria; and Prob $>F$ shows the probability of the null hypothesis. Bold numbers in probability column are higher than 0.05 , which is the rejection criterion indicate a general trend between the similarities due to the conditioning and also show a large range of variation around the general trend line. The significance of this trend decreases from realizations based on Eq. 1 to those based on Eq. 2 and Eq. $3 \quad\left(R_{\mathrm{Eq}_{1}}^{2}=0.58, R_{\mathrm{Eq}_{2}}^{2}=0.68\right.$, $R_{\mathrm{Eq}_{3}}^{2}=0.81$ ). Sand deposits with a large width-to-depth ratio (sheet-like sandbodies) tend to be more connected in a realization, leading to less variable well production values in that realization. The same logic may not be valid for comparing well-level production across realizations where impactful geological parameters for each realization, such as NGR, are significantly different. Figure 15 shows the cumulative production for all 16 producers in the reference
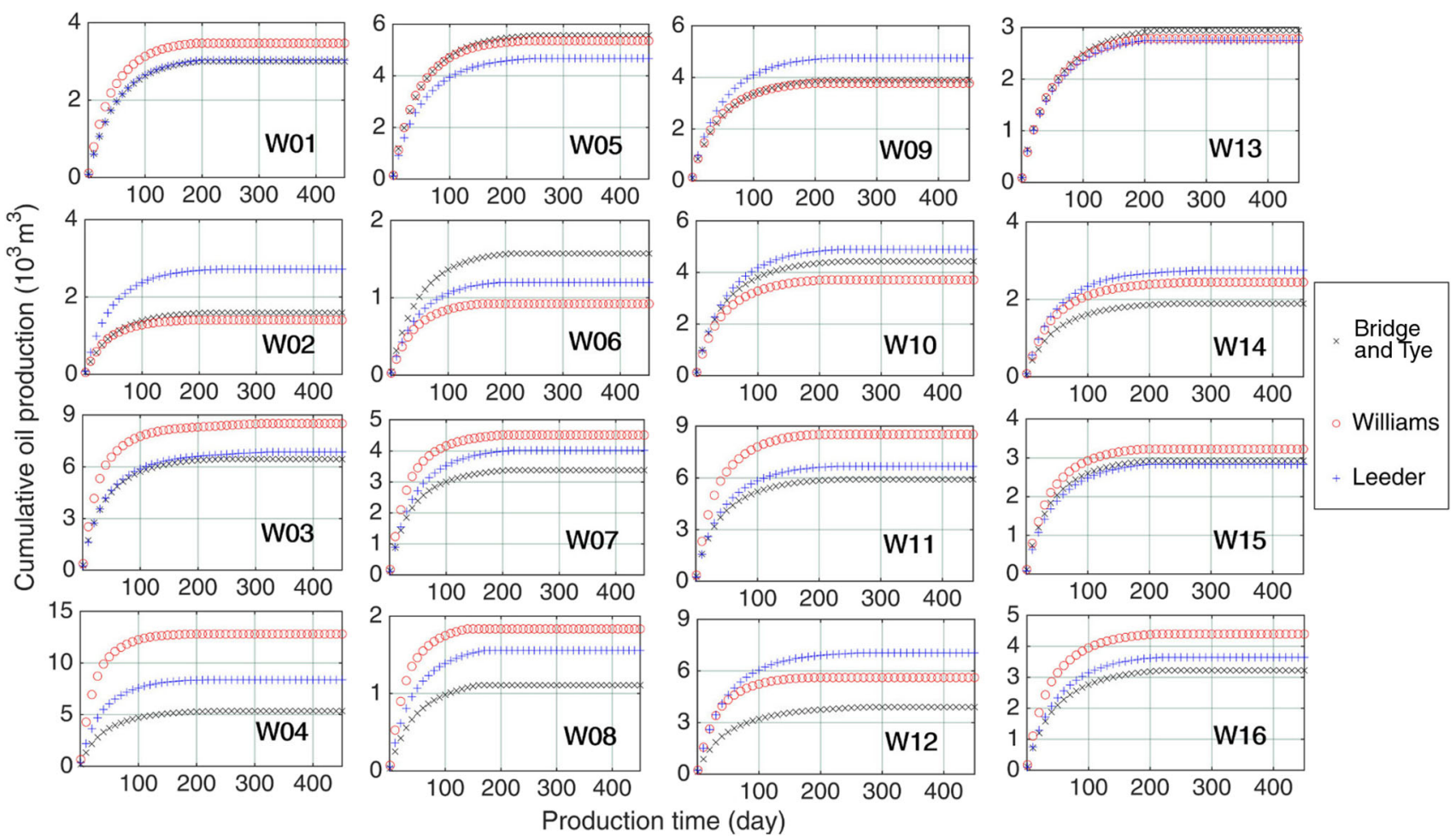

Fig. 15 Comparison between cumulative oil productions of wells by varying the type of equation describing the width of the fluvial channel for a high-NGR case

(see Fig. 15). Scatter plots of the realizations' similarity at field and well levels are provided in Fig. 14c. These graphs model during primary production. A given well's production may change significantly from one realization to the 
next, due to variations in the productive rocks' proportion in each parcel (80 acres around each well).

\subsection{Net-to-gross ratio and cumulative production}

The net-to-gross ratio provides an approximation of the reservoir quality and might be an indicator of the productive geobodies' connectivity. Several authors have studied the connectivity of sandbodies by varying the NGR, e.g., uniformly distributed sand packets (Allen 1979), Boolean models and the truncated Gaussian method (Allard 1993), and the object-based simulation method (Pranter and Sommer 2011). In the present study, NGR is defined as the volumetric proportion of sandbodies (channel lags, point bars, and sand plugs and crevasses) to the total volume of the reservoir. According to this study, the cumulative production of each realization during primary production is correlated strongly with its overall NGR (Fig. 16). Even though one might expect field-level and well-level correlations between NGR and production to be equally as strong, it appears that well-level correlation between NGR and cumulative production may not be as strong. Reservoir architecture dictates the connectivity of productive zones to each well (Fig. 17a). Therefore, architecture plays an important role in defining the production domain of each well. In such cases, regular compartmentalization of the reservoir gives an incorrect estimation of the volume of the productive rocks connected to each well.

Geobody connectivity metrics, described and discussed in Renard and Allard (2013), are helpful in assessing reservoir quality. The connectedness of sands to the wells is defined based on the minimum time-of-flight from each block to wells. The minimum time-of-flight (Datta-Gupta and King 1995) from each well to each block is calculated using Dijkstra's algorithm diffusing and updating the timeof-flight iteratively (Hetland 2014). The travel time through each block is assumed to be proportional to the inverse of the permeability (Fig. 17e). Figure 17b indicates that this metric gives a better approximation. As shown in Fig. 17, cumulative oil production is not correlated with NGR. Even though cumulative oil production appears to be somewhat correlated with sandbody connectedness, this correlation does not appear to be strong enough to be used as a reliable estimator. Since sandbodies are more channellike rather than sheet-like, their lateral extension impacts their connectivity to the wells. In fact, this weak correlation emphasizes the role of preferential paths and connectivity of sandbodies. As shown in Fig. 17, some sandbodies are not connected to their closest wells.

\subsection{Similarity visualization}

As expected, $H_{\max }$ controls the overall NGR. The similarity of the realizations is discussed in Sects. 3.3 and 3.4 based on field- and well-level cumulative production values. The difference in the ultimate cumulative production values may also be used to visualize the similarity between the realizations by projecting them in a metric space using a multi-dimensional scaling technique. This metric space is projected to a higher-dimensional space to increase the models' separability using a radial basis function kernel. This technique has been described in detail in Caers (2011). A 2D projection of realizations in kernel space is

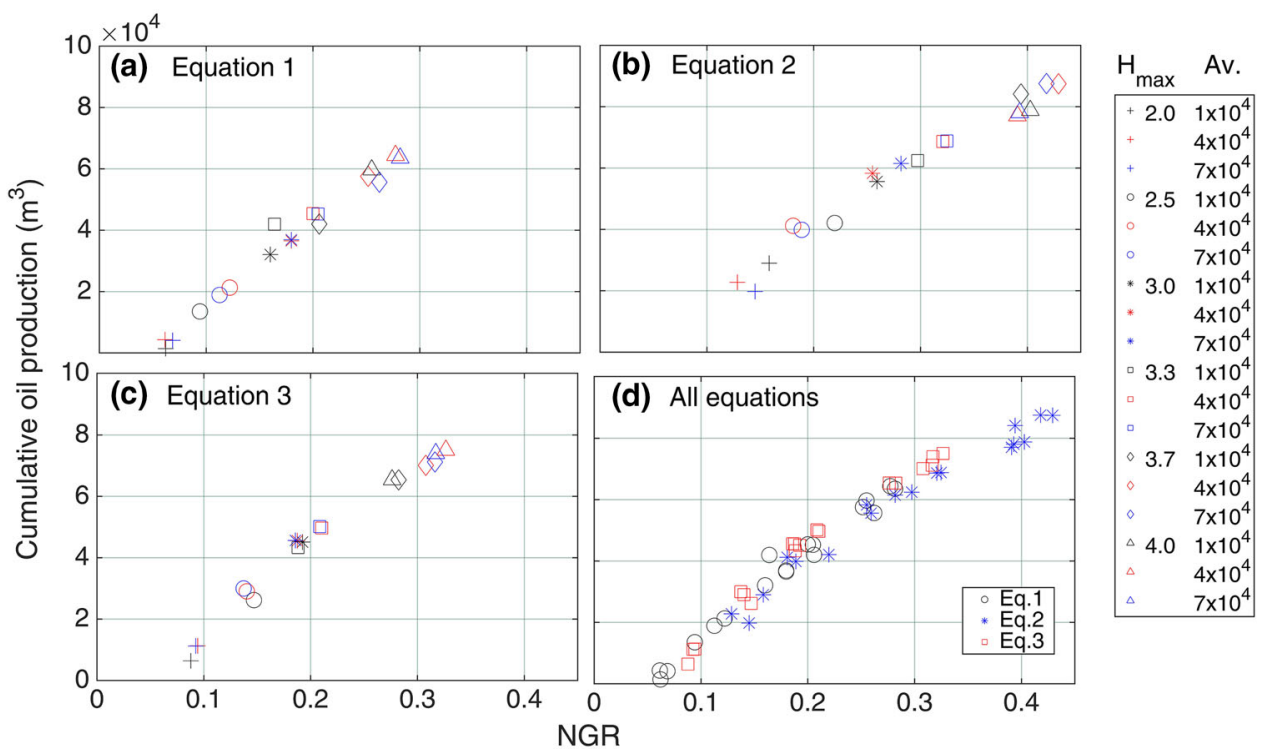

Fig. 16 Relation between overall NGR and total amount of produced oil for reference cases using: a Bridge and Tye's equation, b Williams's equation, $\mathbf{c}$ Leeder's equation, and $\mathbf{d}$ all three cases 

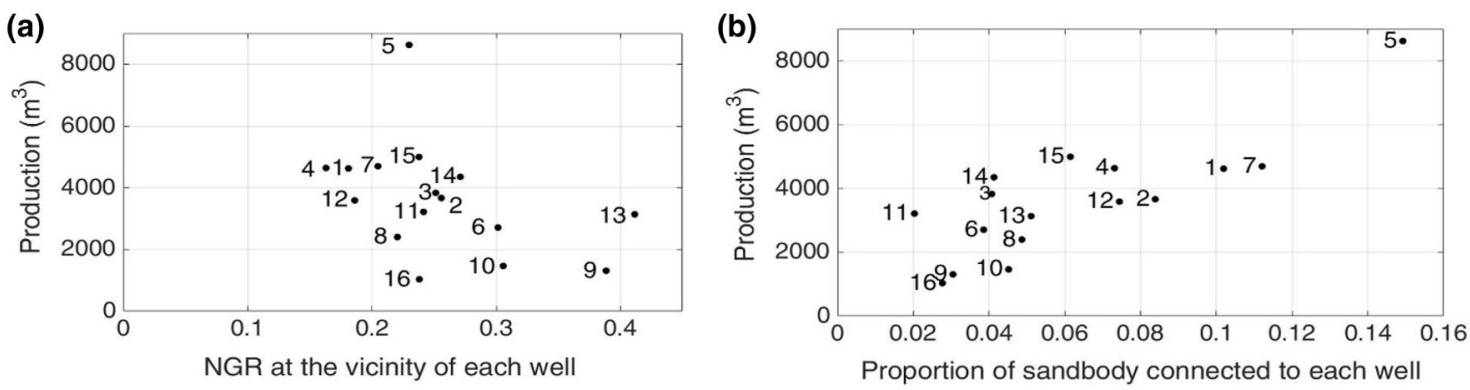

(c)

(d)
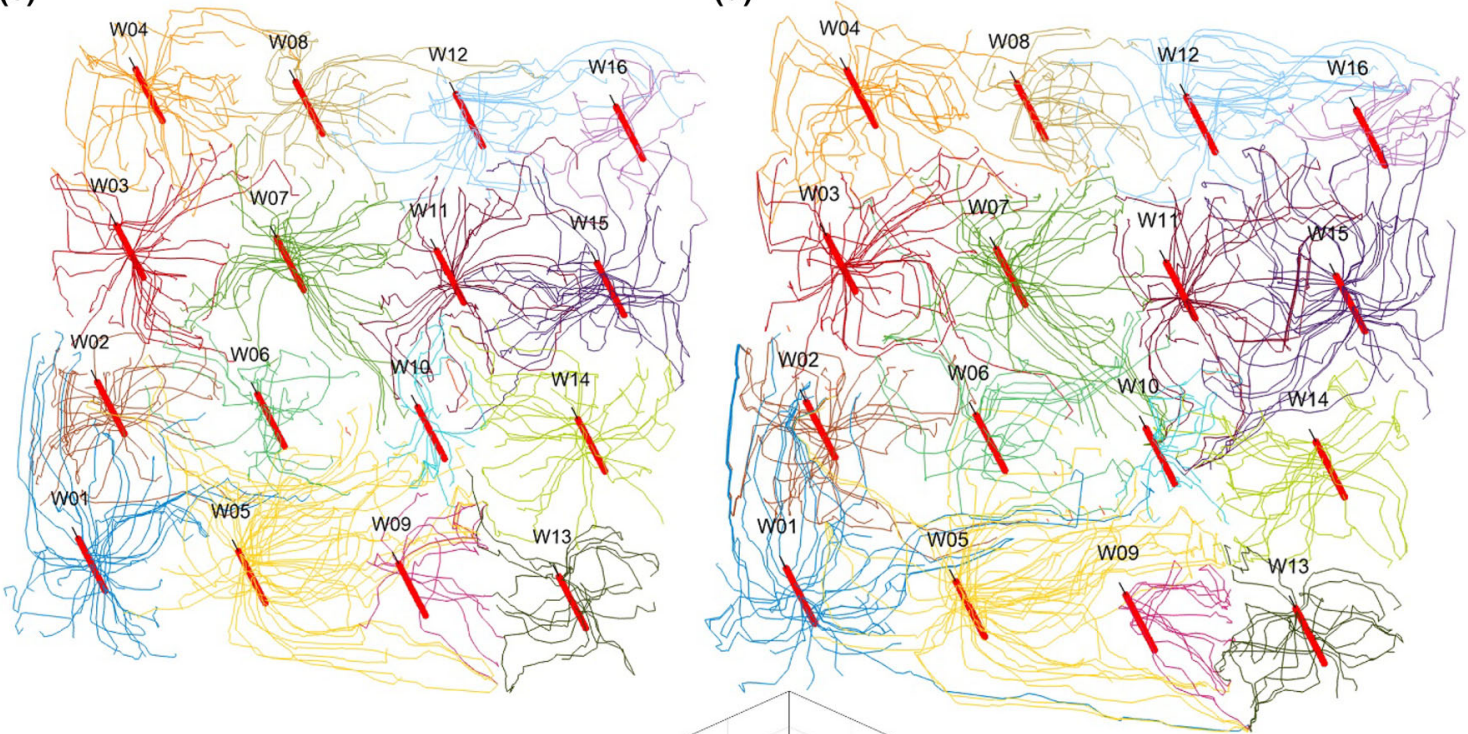

(e)

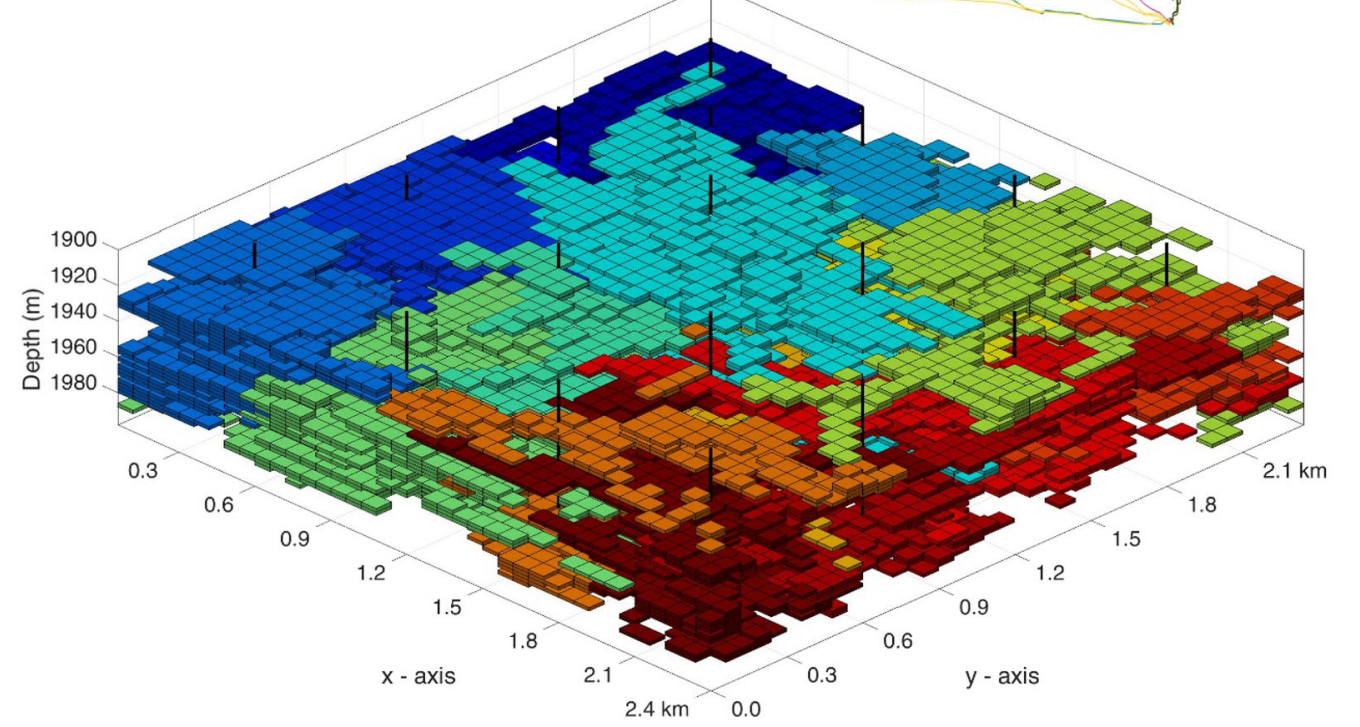

Fig. 17 a Relation between local NGR and wells' total amount of the produced oil (base case according to Williams's equation); b relation between the proportion of the sandbodies connected to each well and

provided in Fig. 18. The coordinates do not have a physical meaning, but the similarity patterns are highlighted. In Fig. 18, there is a tendency for realizations with the same channel depth to be near each other. Proximity of the the total amount of produced oil; c streamline at 60 days; $\mathbf{d}$ at 240 days; e sandbodies connected to wells

realizations is driven most prominently by channel depth, and then equations are used to relate width to depth, and finally avulsion rate. A critical task in modeling meandering reservoirs is the estimation of the depth of fluvial 

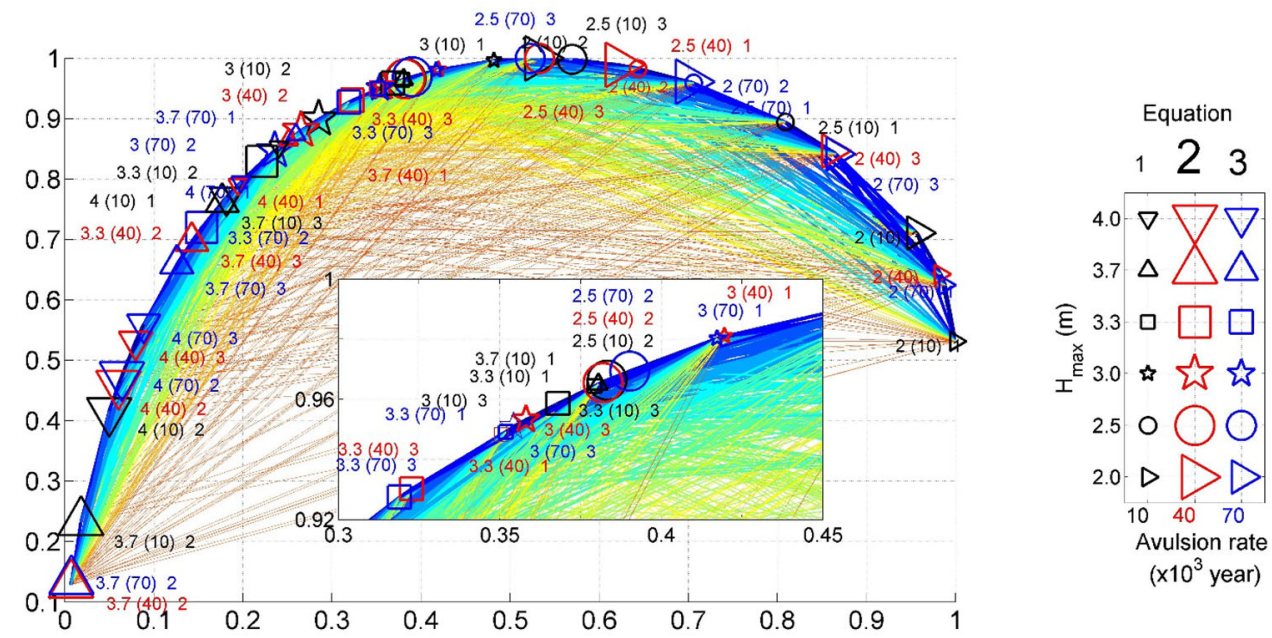

Fig. 18 A 2D projection of the models (realizations) using a radial basis function kernel. The difference of realizations' overall production is shown using a network (blue for small differences, and orange for large differences); symbols are used to represent channel depth; different avulsion rates are distinguished using colors; and the size of

channels based on the thickness of sediment sandbodies. It is necessary to distinguish one-story from multi-story channels and to have an accurate model of sequence stratigraphy for each sedimented feature to differentiate truncated features.

\section{Conclusions}

This work is concerned with the geological uncertainty in fluvial reservoirs. It examines how cumulative oil production is impacted by the main factors that control the architecture of fluvial reservoirs generated by meandering systems.

Simulation results show that reservoir NGR and geometrical parameters of channels impact cumulative production more significantly than avulsion periodicity. Since channel width is a function of the depth of the channel, depth is the most important factor. According to the results of global sensitivity analysis, the estimation of the width of fluvial channels is more important than the avulsion periodicity.

The net-to-gross ratio appears to be a satisfactory metric to evaluate the production potential of fluvial reservoirs, but as shown here, this metric works well only for estimation of production potential at the field level and is inadequate to estimate the well-level production. A better metric to approximate well-level oil production is the portion of the connected sands to each well instead of their proportion at the vicinity of each well. Cumulative oil production is not correlated with NGR. Even though cumulative oil production appears to be somewhat symbol (and the channel width) is determined by the equation used in the calculations. Each field is labeled using three numbers in the following order: $H_{\max }$, avulsion rate (in thousands of years and appearing in parentheses), and equation number

correlated with sandbody connectedness, this correlation does not appear to be strong enough to be used as a reliable estimator.

Acknowledgements The authors thank StreamSim Technologies, FLUMY group, and Schlumberger for providing licenses for the softwares used in this work. The authors are thankful to anonymous reviewers for providing constructive comments.

Open Access This article is distributed under the terms of the Creative Commons Attribution 4.0 International License (http://creative commons.org/licenses/by/4.0/), which permits unrestricted use, distribution, and reproduction in any medium, provided you give appropriate credit to the original author(s) and the source, provide a link to the Creative Commons license, and indicate if changes were made.

\section{References}

Allard D. On the connectivity of two random set models: the truncated Gaussian and the Boolean. Quantitative Geology and Geostatistics. In: Geostatistics Tróia'92; 1993. p. 467-78. https:// doi.org/10.1007/978-94-011-1739-5_37.

Allen JR. Studies in fluviatile sedimentation: an elementary geometrical model for the connectedness of avulsion-related channel sandbodies. Sediment Geol. 1979;24(3-4):253-67. https://doi. org/10.1016/0037-0738(79)90072-1.

Alsouki M, Taifour R, Al Hamad O. Delineating the fluvial channel system in the Upper Triassic formation of the Elward area in the Syrian Euphrates Graben using 3-D seismic attributes. J Pet Explor Prod Technol. 2014;4(2):123-32. https://doi.org/10.1007/ s13202-014-0110-5.

Bridge JS, Mackey SD. A theoretical study of fluvial sandstone body dimensions. In: The geological modelling of hydrocarbon reservoirs and outcrop analogues; 2009. p. 213-36. https://doi. org/10.1002/9781444303957.ch14. 
Bridge JS, Tye RS. Interpreting the dimensions of ancient fluvial channel bars, channels, and channel belts from wireline-logs and cores. AAPG Bull. 2000. https://doi.org/10.1306/a9673c841738-11d7-8645000102c1865d.

Bryant M, Falk P, Paola C. Experimental study of avulsion frequency and rate of deposition. Geol. 1995;23(4):365-8. https://doi.org/ 10.1130/0091-7613(1995)023\%3C0365:ESOAFA\%3E2.3.CO;2.

Byrnes AP. Reservoir characteristics of low-permeability sandstones in the Rocky Mountains. Mt Geol. 1997;34:39-48.

Caers J. Modeling uncertainty in the earth sciences. Hoboken: Wiley; 2011.

Caumon G, Journel AG. Early uncertainty assessment: application to a hydrocarbon reservoir appraisal. In: Leuangthong O, Deutsch CV, editors. Geostatistics Banff 2004. Springer: Dordrecht; 2005. p. 551-7. https://doi.org/10.1007/978-1-4020-3610-1_56.

Cojan I, Fouché O, Lopéz S, Rivoirard J. Process-based reservoir modelling in the example of meandering channel. In: Leuangthong O, Deutsch CV, editors. Geostatistics Banff 2004. Dordrecht: Springer; 2005. p. 611-9. https://doi.org/10.1007/978-14020-3610-1_62.

Collinson JD. Vertical sequence and sandbody shape in alluvial sequences. In: Miall AD, editor. Fluvial sedimentology-AAPG Memoir 5; 1977. p. 577-86.

Comunian A, Jha SK, Giambastiani BM, Mariethoz G, Kelly BF. Training images from process-imitating methods. Math Geosci. 2014;46(2):241-60. https://doi.org/10.1007/s11004-013-9505-y.

Datta-Gupta A, King MJ. A semianalytic approach to tracer flow modeling in heterogeneous permeable media. Adv Water Resour. 1995;18(1):9-24. https://doi.org/10.1016/03091708(94)00021-V.

Deviese ES. Modeling fluvial reservoir architecture using Flumy process. Doctoral dissertation, TU Delft, Delft University of Technology; 2010.

Fielding CR, Crane RC. An application of statistical modelling to the prediction of hydrocarbon recovery factors in fluvial reservoir sequences. In: Ethridge FG, Flores RM, Harvey MD, editors. Recent developments in fluvial sedimentology. Society of Economic Paleontologists and Mineralogists, Special Publications; 1987. p. 321-7. https://doi.org/10.2110/pec.87.39.0321.

Gibling MR. Width and thickness of fluvial channel bodies and valley fills in the geological record: a literature compilation and classification. J Sediment Res. 2006;76(5):731-70. https://doi. org/10.2110/jsr.2006.060.

Hajek EA, Wolinsky MA. Simplified process modeling of river avulsion and alluvial architecture: connecting models and field data. Sediment Geol. 2012;257:1-30. https://doi.org/10.1016/j. sedgeo.2011.09.005

Hastings JO Jr. Coarse-grained meander-belt reservoirs, Rocky Ridge field, North Dakota. In: Barwis JH, editor. Sandstone petroleum reservoirs. Springer: New York; 1990. p. 57-84. https://doi.org/ 10.1007/978-1-4613-8988-0 4.

Hetland ML. Python Algorithms: mastering basic algorithms in the Python Language. New York: Apress; 2014.

Jensen JL. Use of the geometric average for effective permeability estimation. Math Geol. 1991;23(6):833-40. https://doi.org/10. 1007/bf02068778.

Jones LS, Schumm SA. Causes of avulsion: an overview. In: Smith ND, Rogers J, editors. Fluvial sedimentology VI. Oxford: Blackwell Publishing Ltd.; 2009. p. 169-78. https://doi.org/10. 1002/9781444304213.ch13.

Karssenberg D, Tornqvist TE, Bridge JS. Conditioning a processbased model of sedimentary architecture to well data. J Sediment Res. 2001;71(6):868-79. https://doi.org/10.1306/051501710868.

Koneshloo M, Aryana SA, Grana D, Pierre JW. A workflow for static reservoir modeling guided by seismic data in a fluvial system.
Math Geosci. 2017;49(8):995-1020. https://doi.org/10.1007/ s11004-017-9696-8.

Larue DK, Hovadik J. Why is reservoir architecture an insignificant uncertainty in many appraisal and development studies of clastic channelized reservoirs? J Pet Geol. 2008;31(4):337-66.

Lauer JW, Parker G. Modeling framework for sediment deposition, storage, and evacuation in the floodplain of a meandering river: theory. Water Resour Res. 2008;44:W04425. https://doi.org/10. 1029/2006WR005528.

Leeder MR. Fluviatile fining-upwards cycles and the magnitude of paleo-channels. Geol Mag. 1973;110(03):265-76.

Lopez S, Cojan I, Rivoirard J, Galli A. Process-based stochastic modelling: meandering channelized reservoirs. In: de Boer $\mathrm{P}$, Postma G, van der Zwan K, Burgess P, Kukla P, editors. Analogue and numerical modelling of sedimentary systems: from understanding to prediction. Wiley-Blackwell: Special Publ. 40 of the IAS; 2009. p. 139-44. https://doi.org/10.1002/ 9781444303131.ch5.

Lorenz JC, Heinze DM, Clark JA, Searls CA. Determination of widths of meander-belt sandstone reservoirs from vertical downhole data, Mesaverde Group, Piceance Creek basin, Colorado. AAPG Bull. 1985;69(5):710-21. https://doi.org/10. 1306/ad4627ef-16f7-11d7-8645000102c1865d.

Mao S, Journel AG. Generation of a reference petrophysical/seismic data set: the Stanford V reservoir. Stanford: Stanford Center for Reservoir Forecasting Report; 1999.

Massonnat GJ. Can we sample the complete geological uncertainty space in reservoir-modeling uncertainty estimates? SPE J. 2000;5(01):46-59. https://doi.org/10.2118/59801-pa.

Miall AD. Fluvial depositional systems. New York: Springer; 2014.

Nojabaei B, Siripatrachai N, Johns RT, Ertekin T. Effect of saturation dependent capillary pressure on production in tight rocks and shales: a compositionally-extended black oil formulation. In: SPE Eastern Regional Meeting, Charleston, WV, USA; 2014. https://doi.org/10.2118/171028-ms.

Pizzuto JE, Moody JA, Meade RH. Anatomy and dynamics of a floodplain, Powder River, Montana, USA. J Sediment Res. 2008;78(1):16-28. https://doi.org/10.2110/jsr.2008.005.

Pranter MJ, Sommer NK. Static connectivity of fluvial sandstones in a lower coastal-plain setting: an example from the Upper Cretaceous lower Williams Fork Formation, Piceance Basin, Colorado. AAPG Bull. 2011;95(6):899-923. https://doi.org/10.1306/ 12091010008

Pyrcz MJ, Deutsch CV. Geostatistical reservoir modeling. Oxford: Oxford University Press; 2014.

Ramon JC, Cross T. Characterization and prediction of reservoir architecture and petrophysical properties in fluvial channel sandstones, middle Magdalena Basin, Colombia. CT\&F-Ciencia Tecnología y Futuro. 1997;1(3):19-46. https://doi.org/10.1306/ 1d9bbf5d-172d-11d7-8645000102c1865d.

Ren G, Rafiee J, Aryana SA, Younis RM. A Bayesian model selection analysis of equilibrium and nonequilibrium models for multiphase flow in porous media. Int $J$ Multiph Flow. 2017;89:313-20. https://doi.org/10.1016/j.ijmultiphaseflow. 2016.11.006.

Renard P, Allard D. Connectivity metrics for subsurface flow and transport. Adv Water Resour. 2013;51:168-96. https://doi.org/ 10.1016/j.advwatres.2011.12.001.

Rezaee H, Mariethoz G, Koneshloo M, Asghari O. Multiple-point geostatistical simulation using the bunch-pasting direct sampling method. Comput Geosci. 2013;54:293-308. https://doi.org/10. 1016/j.cageo.2013.01.020.

Slatt RM. Stratigraphic reservoir characterization for petroleum geologists, geophysicists, and engineers. Amsterdam: Elsevier; 2006. https://doi.org/10.1016/s1567-8032(06)x8035-7. 
Slingerland R, Smith ND. River avulsions and their deposits. Annu Rev Earth Planet Sci. 2004;32:257-85. https://doi.org/10.1146/ annurev.earth.32.101802.120201.

Strebelle S. Conditional simulation of complex geological structures using multiple-point statistics. Math Geol. 2002;34(1):1-21. https://doi.org/10.1007/s11004-013-9510-1.

Thiele MR, Batycky RP, Blunt MJ. A streamline-based 3d field-scale compositional reservoir simulator. In: SPE Annual Technical Conference and Exhibition 1997 Jan 1. Society of Petroleum Engineers; 1997. https://doi.org/10.2523/38889-ms.

Tye RS. Quantitatively modeling alluvial strata for reservoir development with examples from Krasnoleninskoye Field, Russia. J Coast Res. 2013;69(sp1):129-52. https://doi.org/10.2112/si_ 69_10.
Utts JM, Heckard RF. Mind on statistics. Boston: Cengage Learning; 2011.

Williams GP. River meanders and channel size. J Hydrol. 1986;88(1-2):147-64. https://doi.org/10.1016/00221694(86)90202-7.

Zhang T, Zhang X, Lin C, Yu J, Zhang S. Seismic sedimentology interpretation method of meandering fluvial reservoir: from model to real data. J Earth Sci. 2015;26(4):598-606. https://doi. org/10.1007/s12583-015-0572-5.

Zhang Y, Song C, Zheng S, Yang DT. Simultaneous estimation of relative permeability and capillary pressure for tight formations from displacement experiments. In: SPE Canadian Unconventional Resources Conference 2012 Jan 1. Society of Petroleum Engineers; 2012. https://doi.org/10.2118/162663-ms. 